\title{
As mulheres que acompanharam as rainhas de Portugal. Os séquitos femininos de Leonor Teles, Filipa de Lencastre e Leonor de Aragão (1371-1445)
}

\author{
Mariana Raquel Faria da Silva \\ marianaraque1999@gmail.com
}

\section{Resumo}

Este artigo tem como objectivo estudar as mulheres que compunham o séquito de Leonor Teles, Filipa de Lencastre e Leonor de Aragão, três rainhas medievais portuguesas. Estas mulheres são muitas vezes esquecidas, apesar de terem desempenhado um importante papel na vida das rainhas que serviam, e por isso, através do estudo de crónicas, e das chancelarias, e com recurso a bibliografia especializada, procurou-se dar a conhecer os nomes, as famílias, os cargos e alguns episódios das vidas destas senhoras. Procurou-se também entender a importância da Casa da Rainha na sociedade medieval portuguesa. Em anexo, seguem quatro esquemas genealógicos, elaborados com base na investigação efectuada e que visam mostrar as relações familiares entre as damas referidas no artigo.

Palavras-chave: Casa da Rainha, família, genealogia, medieval, mulher, rainha, séquito, sociedade.

\begin{abstract}
This article aims to study the women who made up the entourage of Leonor Teles, Filipa de Lencastre and Leonor de Aragão, three Portugueses medieval queens. These women are often overtlooked, despite having played na importat role in the lives of the queens they served, and therefore, through the study of chionicles and chancelleries, and using the specialized bibliography, devoted making themselves known, families, positions and some episodes of the ladies lives. We also sought to understand the importance of Casa da Rainha in medieval Portuguese society. Attachef are four genealogical schemes, elaborated based on the research carried out na which aim to show how family relationships among the ladies mentioned in the article.
\end{abstract}

Keywords: Queen's House, family, genealogy, medieval, woman, queen, entourage, society. 
Silva, Mariana Faria da - As mulheres que acompanharam as rainhas de Portugal. Os séquitos femininos de Leonor Teles, Filipa de Lencastre e Leonor de Aragão (1371-1445). In Omni Tempore-Atas dos Encontros da Primavera 2020. Porto: FLUP, 2021. pp. 143-176.

\section{Introdução}

Este artigo pretende dar a conhecer algumas mulheres que serviram D. Leonor Teles, mulher de D. Fernando, D. Filipa de Lencastre, casada com D. João I e D. Leonor de Aragão, esposa de D. Duarte, três rainhas medievais portuguesas.

As senhoras que compunham os séquitos das soberanas desempenharam um importante papel na vida destas, estando presentes, não só nos momentos mais marcantes, como o casamento e o nascimento dos filhos, por exemplo, mas também no seu dia-a-dia.

Os elementos, tanto masculinos como femininos, que faziam parte da Casa das rainhas, são muitas vezes esquecidos e pouco ou nada se sabe sobre as suas vidas, seja por falta de fontes ou por terem desempenhado um papel secundário. Neste artigo, debruçamo-nos sobre as mulheres, e tentamos resgatar um pouco do papel que desempenharam na História.

Contudo, nem todas as mulheres que se encontravam ao serviço de uma rainha cairiam no esquecimento e muitas delas são relembradas pela História. Vataça Lascaris e Inês de Castro são exemplo disso.

Vataça Lascaris pertencia ao séquito de D. Isabel de Aragão, esposa de D. Dinis, tendo depois acompanhado a infanta D. Constança, filha dos monarcas, quando esta casou, desempenhando o cargo de sua camareira-mor ${ }^{1}$. O seu túmulo encontra-se na Sé Velha de Coimbra e foi executado pelo mesmo autor do túmulo da rainha D. Isabel, o que pode demonstrar a amizade entre ambas. Inês de Castro teria chegado a Portugal enquanto elemento do séquito de D. Constança Manuel, quando esta casou com o futuro rei D. Pedro I e a sua história é sobejamente conhecida.

Para comprovar a importância destas senhoras na vida da rainha e da sua família, destaca- se o túmulo de D. Urraca, mulher de D. Afonso II, no Mosteiro de Alcobaça. Este cenotáfio tem esculpido uma Cena de Lamentação, onde estarão representados o rei e os infantes a chorar a morte da rainha, mas também uma ama do infante D. Sancho (futuro rei D. Sancho II), Teresa Martins de Riba de Vizela ${ }^{2}$. A comprovar a identificação desta personagem, isso pode demonstrar a relevância do papel das servidoras junto da família real.

Nenhuma destas três mulheres será referida no artigo, uma vez que não se enquadram na cronologia abordada. No entanto, consideramos importante mencioná-las, por serem exemplos de personagens próximas da Coroa que se distinguiram.

A Casa da Rainha desempenhava um importante papel na corte e na vida de muita gente. Sobre D. Isabel de Aragão, que não é abordada no trabalho, Ana Rodrigues Oliveira diz que:

\footnotetext{
${ }^{1}$ OLIVEIRA, Ana Rodrigues - Rainhas Medievais de Portugal. Lisboa: A Esfera dos Livros, 2010. p. 163.

${ }^{2}$ Idem, p. 108.
} 
Silva, Mariana Faria da - As mulheres que acompanharam as rainhas de Portugal. Os séquitos femininos de Leonor Teles, Filipa de Lencastre e Leonor de Aragão (1371-1445). In Omni Tempore-Atas dos Encontros da Primavera 2020. Porto: FLUP, 2021. pp. 143-176.

em sua Casa criava muitas filhas de nobres e de cavaleiros e outras que não tinham a possibilidade de se manterem por si em vida independente. Educava-as, alimentava-as e dava-lhes dote para o casamento. Preocupada com o seu futuro, preparava-as para a sua vida de esposas e mães (...). Procurava-lhes, depois, marido entre a vassalidade da corte de D. Dinis (..), a outras (...) abria-lhes as portas dos mosteiros fundados com recursos (...) para as assistir (...). Para além das donas da sua Casa, a rainha preocupou-se ainda com as suas criadas e mancebas mais pobres, dotando-as para que pudessem conseguir um matrimónio que lhes desse uma vida honrada. ${ }^{3}$

Podemos supor que este exemplo possa ter sido seguido pelas rainhas que a sucederam, mas pelo menos, este excerto define a importância do séquito feminino para a proteção das damas da corte. Pretende-se, assim, traçar a composição feminina dos séquitos destas três rainhas, acompanhando o desenvolvimento e o desenrolar de vários episódios de relevo da História de Portugal. Sobre as mulheres que acompanharam Leonor Teles, Filipa de Lencastre e Leonor de Aragão, a quem será dada voz neste artigo, tentamos descobrir um pouco sobre as suas vidas, sobre as suas famílias e sobre episódios que viveram junto da soberana.

\section{Contextualização histórica}

A cronologia deste trabalho situa-se entre os anos de 1371, ano em que Leonor Teles terá casado secretamente com D. Fernando, e 1445, ano em que Leonor de Aragão terá falecido. Aborda o reinado de D. Fernando, a regência de Leonor Teles, o reinado de D. João I, a partir do seu casamento com D. Filipa, passando pelo casamento e reinado de D. Duarte e os tempos que se seguiram ao seu falecimento até à morte de D. Leonor de Aragão.

\section{A Casa da Rainha}

A Casa da Rainha representava não só a casa que recebia a soberana e o seu séquito, mas também a gestão, a nível social e financeiro, que as rainhas tinham de fazer, a fim de assegurar o sustento dos seus servidores ${ }^{4}$ e o seu próprio nível de vida. Representava ainda o património, as terras e os servidores das soberanas.

Esta Casa tinha funcionários próprios provenientes das terras que as rainhas recebiam em arras e estes servidores sustentavam a estrutura dos seus aposentos, intervindo, de forma direta e indireta, nas suas ações políticas e religiosas.

A presença de mulheres nas cortes régias esteve desde sempre ligada à figura da rainha, que era o elemento central deste mundo feminino ${ }^{5}$, ainda que também existissem mulheres ao serviço do rei. Estas pertenceriam a escalões sociais inferiores e estariam encarregues da limpeza e da alimentação da câmara régia.

\footnotetext{
${ }^{3}$ Idem, pp. 169-170.

${ }^{4}$ BALEIRAS, Isabel de Pina - Uma rainha inesperada. Leonor Teles. Lisboa: Círculo de Leitores, 2012. p. 122.

${ }^{5}$ GOMES, Rita Costa - A Corte dos Reis de Portugal no Final da Idade Média. Oeiras: Difel, 1995. p. 46.
} 
Silva, Mariana Faria da - As mulheres que acompanharam as rainhas de Portugal. Os séquitos femininos de Leonor Teles, Filipa de Lencastre e Leonor de Aragão (1371-1445). In Omni Tempore-Atas dos Encontros da Primavera 2020. Porto: FLUP, 2021. pp. 143-176.

As mulheres de nível social elevado procuravam um lugar junto da soberana, enquanto membro do seu séquito ou Casa, sendo esse um lugar preferencial para elas.

A Casa da Rainha era composta por elementos masculinos e femininos (com laços de parentesco que os uniam aos cortesãos do rei), cujas funções se distinguiam, cabendo às mulheres o cuidado das crianças e da alimentação. Deviam também acompanhar a rainha.

Quando uma nova consorte chegava ao seu reino de acolhimento, viria acompanhada por um grupo de mulheres, suas familiares ou da sua clientela, que constituíam uma parte importante do seu séquito. Algumas destas mulheres seriam jovens, outras teriam mais maturidade, com autoridade sobre as damas mais jovens. Poderia, até, vir uma aia que tivesse acompanhado o crescimento da rainha A presença destas senhoras junto da soberana deveria dar-lhe algum conforto, pois vinham com ela do seu reino de origem e já a deveriam conhecer. Além disso, falavam a mesma língua, conheciam os mesmos costumes e estavam, tal como ela, numa terra nova e desconhecida. Ana Rodrigues Oliveira, na sua obra Rainhas Medievais de Portugal, diz que "para tentar minorar as perturbações afectivas que esse corte vivencial acarretaria, prevalecia o princípio de as procurarem confiar aos cuidados de mulheres de uma mais ou menos próxima parentela, ao mesmo tempo que as faziam acompanhar, na sua transferência familiar, por alguns daqueles que lhes haviam seguido os primeiros tempos, como era o caso das amas, aias ou serviçais (...)"6. Muitas destas mulheres teriam sido, quem sabe, confidentes dos medos e preocupações das rainhas.

Ao chegar ao seu reino de casamento, encontravam outras mulheres que procuravam um lugar no seu séquito, a fim de acrescentar prestígio e rendimento às suas famílias ${ }^{7}$. Além disso, desempenhavam funções de integração, ao ajudar a rainha a conhecer melhor o seu novo reino. À rainha, cabia sustentar e ocupar o seu séquito, assim como arranjar casamentos apropriados para as damas solteiras e as terras que as rainhas recebiam no momento dos seus casamentos serviriam para constituir a sua "Casa", sustentando, como já foi dito, os seus servidores.

Dentro deste gineceu que rodeava a soberana existia uma hierarquia entre as mulheres casadas (as donas) e as solteiras (as donzelas), sendo o casamento um dos factores de distinção entre elas. Além do estado civil, as famílias a que pertenciam ditavam também esta hierarquia.

A presença das donzelas na corte tinha como objectivo encontrar um casamento apropriado. Estavam mais dependentes da rainha e tinham uma esfera de acção mais reduzida. Caso não casassem, pretendiam garantir uma vida tranquila na corte ${ }^{8}$.

${ }^{6}$ OLIVEIRA, Ana Rodrigues - Rainhas Medievais de Portugal... p. 163.

${ }^{7}$ SILVA, Manuela Santos - A rainha inglesa de Portugal. Filipa de Lencastre. Lisboa: Círculo de Leitores. p. 181.

${ }^{8}$ BALEIRAS, Isabel de Pina - Uma rainha inesperada. Leonor Teles... p. 122. 
Silva, Mariana Faria da - As mulheres que acompanharam as rainhas de Portugal. Os séquitos femininos de Leonor Teles, Filipa de Lencastre e Leonor de Aragão (1371-1445). In Omni Tempore-Atas dos Encontros da Primavera 2020. Porto: FLUP, 2021. pp. 143-176.

Além disto, as donzelas podiam ser educadas junto da rainha, ou seja, ser da sua "criação"9. De facto, a situação das donzelas podia ser aproximada à situação das criadas da rainha. O que se entendia por "criada" (ou "criado", no caso dos rapazes) era diferente dos significados actuais do termo ${ }^{10}$. Segundo Rita da Costa Gomes, “com a «criação» aproximamo-nos de uma relação duradoura que assume uma verdadeira forma de pseudo-parentesco"11. As criadas estavam junto da soberana, a quem cabia educar, propiciar meios de subsistência e arranjar um casamento apropriado.

As donas eram senhoras casadas ou viúvas e gozavam de maior autonomia, podendo desempenhar o cargo de aias ou camareiras, função de maior proximidade à soberana. Estas senhoras, de elevado nível social, estavam diretamente dependentes da rainha ${ }^{12}$.

Além das donas e das donzelas, existiam também as "ricas-donas", filhas, mulheres ou viúvas de ricos-homens e detentoras de casa própria, podendo, no caso das filhas, ser donzelas. Devido à sua riqueza material e património próprio, tinham uma maior autonomia face à rainha, pois através das suas heranças, podiam sustentar a sua independência ${ }^{13}$. Era um critério de distinção hierárquica, e aparecem muitas vezes mencionadas em documentos, como por exemplo, em testamentos das rainhas. Rita Costa Gomes menciona uma tabela de legados testamentários deixados pela rainha D. Beatriz de Castela, em 1358, às mulheres que a serviram. Embora esta rainha não faça parte da cronologia por nós abordada nesta investigação, é pertinente observar os valores: por casamento, as Ricas-donas receberiam mil libras, seguindo-se as Donas e por fim as Donzelas, que receberiam quinhentas libras, independentemente da sua linhagem. Isto é um bom exemplo da hierarquização existente na corte. No século $\mathrm{XV}$, a designação de Rica-dona tornou-se mais rara, mas a distinção entre Donas e Donzelas manteve-se ${ }^{14}$.

$\mathrm{Na}$ corte circulavam também religiosas, como as donas do Mosteiro de Santos (mosteiro feminino pertencente à Ordem Militar de Santiago), em Lisboa. As mulheres que ingressavam nesta comunidade eram oriundas da nobreza, não estavam sujeitas ao voto de celibato nem de clausura, tinham património próprio, que podiam gerir, e podiam manter as filhas junto de $\mathrm{si}^{15}$.

Seguiam-se as funcionárias do gineceu, como as camareiras. A camareira-mor era uma mulher da confiança da soberana e estava ligada à sua intimidade, tendo a seu cargo o deitar, levantar, vestir e lavar da sua senhora. Tinha também a função de vigiar as restantes servidoras ${ }^{16}$.

\footnotetext{
${ }^{9}$ Idem, p. 123.

${ }^{10}$ GOMES, Rita Costa - A Corte dos Reis de Portugal no Final da Idade Média... p. 180.

${ }^{11}$ Idem, p. 185.

${ }^{12}$ Idem, p. 54.

${ }^{13}$ Idem, p. 99.

${ }^{14}$ Idem, p. 55

${ }^{15}$ Idem, p. 56.

${ }^{16}$ RODRIGUES, Ana Maria S. A. - As tristes rainhas. Leonor de Aragão, Isabel de Coimbra. Lisboa: Círculo de Leitores, 2012. p. 160.
} 
Silva, Mariana Faria da - As mulheres que acompanharam as rainhas de Portugal. Os séquitos femininos de Leonor Teles, Filipa de Lencastre e Leonor de Aragão (1371-1445). In Omni Tempore-Atas dos Encontros da Primavera 2020. Porto: FLUP, 2021. pp. 143-176.

As covilheiras tinham como função velar pelo corpo e pela intimidade da rainha, podendo assistir aos partos e aos cuidados da primeira infância dos filhos dos reis. Ocupavam-se das vestes da rainha e dos seus filhos. Confundiam-se com as amas, que cuidavam das crianças e por vezes substituíam a mãe na alimentação das mesmas. As amas eram muitas vezes recompensadas pelos reis de quem tinham cuidado, quando estes eram crianças ${ }^{17}$. Covilheiras e amas desempenhavam um importante papel no bem-estar das crianças, não só filhos dos monarcas, como dos filhos de nobres que estavam a ser criados na corte ${ }^{18}$. Conclui-se assim que o gineceu era indissociável das crianças pequenas que viviam na corte.

As mancebas ocupavam lugares mais baixos na hierarquia e, ao contrário das servas e mouras (as escravas domésticas), eram livres. Poderiam corresponder ao conceito atual de "criada", podendo estar responsáveis pela limpeza e arrumação dos aposentos da soberana.

Verifica-se assim a importância do papel da rainha para as fidalgas do reino, bem como dos séquitos femininos que garantiam o funcionamento da corte e auxiliavam no quotidiano da rainha. No entanto, caso não existisse uma rainha, o gineceu podia ser gerido pela mãe, uma filha ou uma irmã do monarca, como foi o caso de D. Beatriz (filha de D. Pedro I e irmã de D. Fernando) e da infanta D. Isabel (fillha de D. João I e irmã de D. Duarte), casos de que falaremos.

Mas seriam só as rainhas a ter um séquito? Segundo Fernão Lopes, D. Maria Teles, irmã de D. Leonor Teles:

era de gran casa de donas e donzelas e camareiras e outra gente miúda (...). Havia coração e abastança para o fazer, porque o mestrado de Christo lhe fôra dado para D. Lopo Dias, seu filho, e as rendas eram postas em seu poder, afora muitos herdamentos moveis e de raiz e muito bem-fazer da rainha sua irmã. ${ }^{19}$

Além disso, terá sido uma camareira, Margarida Lourenço, a intermediária dos amores entre D. Maria e D. João, filho de D. Pedro I e D. Inês de Castro ${ }^{20}$. Assim, verifica-se que não eram só as rainhas que possuíam um séquito, pois de acordo com Fernão Lopes, Maria Teles tinha um, que sustentava com as suas possibilidades financeiras.

\subsection{Aposentos}

Como vimos, os séquitos das rainhas eram compostos por um grande número de pessoas que precisavam de ser instaladas nos paços reais.

Ao contar o episódio do assassinato de D. Maria Teles, Fernão Lopes, na sua Crónica de D. Fernando, descreve a casa onde ela se encontrava, começando por contar que D. João e o grupo

\footnotetext{
${ }^{17}$ GOMES, Rita Costa - A Corte dos Reis de Portugal no Final da Idade Média ... p. 57.

${ }^{18}$ Idem, pp. 56-57.

19 LOPES, Fernão - Crónica de D. Fernando. Lisboa: Escriptorio, 1895-1896. (Biblioteca de clássicos portugueses). Cap. C, p. 140.

${ }^{20}$ Idem.
} 
Silva, Mariana Faria da - As mulheres que acompanharam as rainhas de Portugal. Os séquitos femininos de Leonor Teles, Filipa de Lencastre e Leonor de Aragão (1371-1445). In Omni Tempore-Atas dos Encontros da Primavera 2020. Porto: FLUP, 2021. pp. 143-176.

que com ele seguia, ao entrar, “(...) subiram acima, a uma sala onde jaziam algumas mulheres dormindo" $" 21$. O cronista refere ainda a existência de duas câmaras, estando D. Maria a dormir numa delas, e na outra, "(...) detraz d'aquela jazia uma ama e camareiras, com um seu filho."22

Com esta leitura, supõe-se que existiria uma sala onde dormiam algumas pessoas, mulheres, possivelmente donzelas e criadas. As divisões privadas, ou câmaras, seriam ocupadas por pessoas de alta posição social, como a rainha, e ainda crianças e as suas amas.

Segundo Manuela Santos Silva, nestes espaços, além de dormir, podia-se comer, jogar e conviver, existindo mesas que eram montadas e desmontadas para as refeições. Para se sentarem, eram utilizadas camas, arcas, bancos e o chão, em tapetes e almofadas. Na câmara ou na antecâmara da rainha existia também o estrado, onde as senhoras se entretinham nas suas atividades femininas: jogos, leituras, conversas, bordados e costumes. ${ }^{23}$

Também Gomes Eanes de Zurara, na sua Crónica da Tomada de Ceuta, conta que D. João I informou D. Filipa de Lencastre da sua participação na tomada desta praça, “(...) estamdo huu dia follgamdo na camara da dita senhora, seemdo hi açercua de seu estrado Briatiz Gomçallvez de Moura e sua filha Meçia Vaasquez (...)"24. Este excerto é importante, pois menciona o estrado existente na câmara da rainha e também duas das senhoras que compunham o seu gineceu.

De acordo com Manuela Santos Silva, quando a corte estanciava em cidades, vilas ou arraiais militares, a soberana e o seu séquito podiam acompanhar o rei e os seus cortesãos, ficando hospedadas em aposentos diferentes uns dos outros, desde solares junto às muralhas, zonas nas alcáçovas dos castelos, paços propositadamente construídos para albergar a comitiva, casas ou paços de vassalos ou familiares, mosteiros ou em tendas de campanha ${ }^{25}$.

Fernão Lopes descreve ainda a festa organizada por D. Isabel de Castro, filha de D. Álvaro Peres de Castro e donzela da Casa de D. Leonor Teles, “(...) em umas casas cerca dos paços onde ella pousava, como moradora que era da rainha"26. Depois, “(...) partiam para o paço (...) com D. Isabel muitas donas e donzellas, e assim chegaram ao paço onde el rei e a rainha estavam, de quem foram mui bem recebidos (...)"27. Com este excerto, conclui-se que D. Isabel se encontrava alojada nos paços junto da rainha, mas em eventos privados, como foi o caso desta

\footnotetext{
${ }^{21}$ Idem, p. 154.

${ }^{22}$ Idem.

${ }^{23}$ SILVA, Manuela Santos-A rainha inglesa de Portugal. Filipa de Lencastre. Lisboa: Círculo de Leitores.

${ }^{24}$ ZURARA, Gomes Eanes - Crónica da Tomada de Ceuta. Publicada por ordem da Academia das Ciências de Lisboa segundo os manuscritos n 368 e 355 do Arquivo Nacional por Francisco Maria Esteves Pereira. Lisboa: Academia das Ciências, 1915. p. 119.

${ }^{25}$ SILVA, Manuela Santos-A rainha inglesa de Portugal. Filipa de Lencastre. Lisboa: Círculo de Leitores.

${ }^{26}$ LOPES, Fernão - Crónica de D. Fernando... Vol. II, p. 149.

${ }^{27}$ Idem, p. 150.
} 
Silva, Mariana Faria da - As mulheres que acompanharam as rainhas de Portugal. Os séquitos femininos de Leonor Teles, Filipa de Lencastre e Leonor de Aragão (1371-1445). In Omni Tempore-Atas dos Encontros da Primavera 2020. Porto: FLUP, 2021. pp. 143-176.

festa, arranjou umas casas próximas dos aposentos reais, as quais poderá ter alugado (ou aforado) ou utilizado.

Até ao século XVI, os reis costumavam viajar, circulando pelo reino, permanecendo, anualmente, em mais do que um paço. Seriam acompanhados pelas suas comitivas, mas isto leva-nos a uma nova questão: será que a rainha levava consigo todos os elementos do seu séquito nestas deslocações? Manuela Santos Silva diz que não e é da opinião que a soberana estaria acompanhada por um número elevado de senhoras e de oficiais e servidores, que podiam variar de acordo com a localidade em que se encontrava. ${ }^{28}$

\section{D. Leonor Teles}

Filha de Martim Afonso Telo e de Aldonça de Vasconcelos e irmã de João Afonso Telo, Gonçalo Teles e Maria Teles. Tinha ainda uma irmã ilegítima, Joana Teles ${ }^{29}$.

Leonor Teles terá conhecido ou reencontrado D. Fernando, rei desde 1367, durante uma visita que fez à sua irmã, D. Maria Teles, que integrava o séquito de D. Beatriz, filha de D. Pedro I e de D. Inês de Castro e meia-irmã de D. Fernando. No entanto, quando se conheceram, D. Leonor era casada com João Lourenço da Cunha, senhor de Pombeiro, com quem tinha um filho, Álvaro da Cunha. Ao casar com o rei de Portugal, terá negado ser mãe de Álvaro, chamando- lhe Álvaro de Sousa e dando-o como filho de Lopo Dias de Sousa e de uma mulher da sua casa, de nome Elvira ${ }^{30}$. Esta mulher estaria junto de Leonor Teles ainda antes de esta se ter tornado rainha. Não se sabe, contudo, se a terá continuado a servir depois do seu casamento com o rei.

\subsection{Antes da rainha: o séquito de D. Beatriz}

O papel feminino mais importante da corte era desempenhado por D. Beatriz desde o reinado de seu pai, uma vez que D. Pedro I nunca casou nos dez anos em que reinou, pelo que não existia uma rainha consorte. Além disso, a mãe do rei, a rainha D. Beatriz de Castela, falecera em 1359, e a infanta D. Maria, a filha que nascera do seu casamento com D. Constança Manuel, estava casada em Castela. Também as irmãs do monarca, D. Maria, rainha de Castela e D. Leonor, rainha de Aragão tinham já falecido.

Com a morte de D. Pedro, sucedeu-lhe o seu filho, D. Fernando, que à época da sua subida ao trono não era casado. Assim, a sua irmã continuou a exercer o papel de mulher mais importante da corte, junto de quem muitas senhoras procuraram proteção. Segundo Fernão Lopes

\footnotetext{
${ }^{28}$ SILVA, Manuela Santos-A rainha inglesa de Portugal. Filipa de Lencastre. Lisboa: Círculo de Leitores.

${ }^{29}$ BALEIRAS, Isabel de Pina - Uma rainha inesperada. Leonor Teles... p. 27.

${ }^{30}$ LOPES, Fernão - Crónica de D. João I. Segundo o códice $\mathrm{n}^{\circ} 352$ do Arquivo Nacional da Torre do Tombo. Introdução de Humberto Baquero Moreno e prefácio de António Sérgio. Porto: Livraria Civilização, 1983. Vol. 2, p. 396.
} 
Silva, Mariana Faria da - As mulheres que acompanharam as rainhas de Portugal. Os séquitos femininos de Leonor Teles, Filipa de Lencastre e Leonor de Aragão (1371-1445). In Omni Tempore-Atas dos Encontros da Primavera 2020. Porto: FLUP, 2021. pp. 143-176.

“(...) reinando el-rei D. Fernando, (...) trazia sua irmã D. Beatriz, filha que fora de D. Ignez e d'el-rei D. Pedro seu pae, gran casa de donas e donzellas, filhas d'algo e de linhagem, porque ahi não havia rainha nem outra infante, por então, a cuja mercê se houvessem de $\operatorname{acostar}(\ldots)^{\prime \prime 31}$.

D. Beatriz terá desempenhado esta função durante cerca de treze anos: entre 1359, ano em que a sua homónima avó faleceu e 1371 (ano em que o rei D. Fernando terá casado secretamente com Leonor Teles) ou 1372 (data do casamento público do mesmo casal régio), passando o reino e a corte a ter uma rainha.

\subsection{Casa da rainha Leonor Teles}

A 5 de Janeiro de 1372, D. Fernando outorgou uma carta de arras a D. Leonor, na qual lhe eram concedidas terras para o seu sustento e que lhe permitiriam constituir a sua própria Casa.

Enquanto rainha e esposa do rei, D. Leonor Teles substituía D. Beatriz como a mulher mais importante da Corte. Mas como se terá processado a transmissão do séquito da irmã do rei para a nova soberana? Será que as mulheres que serviam D. Beatriz passaram a servir D. Leonor, ou continuaram o seu serviço junto dela? São questões às quais não conseguimos, até à data, responder com certeza. Sabe-se, contudo, que D. Leonor terá, nas palavras de Fernão Lopes, feito "muitos e bons casamentos"32. A rainha fez ainda várias mercês, não só aos noivos que casou, como a outros fidalgos, o que terá sido uma tentativa por parte de Leonor de granjear aliados e apoiantes, visto que a sua união com o monarca não foi bem aceite pela sociedade.

Pode-se concluir que as mulheres que D. Leonor Teles casou faziam parte do seu séquito, enquanto donzelas que procuravam um bom casamento junto da soberana. Algumas das noivas eram suas familiares, como foi o caso de sua irmã, Joana Teles e de Inês Dias Botelho, sua parente. Mécia Vasques Coutinho e Teresa de Meira, sendo que esta última foi aia da filha de Leonor Teles, a infanta D. Beatriz, também tiveram os seus casamentos arranjados pela rainha, assim como Beatriz Nunes, Sancha Andeiro (filha de João Fernandes de Andeiro), uma filha do arcebispo de Braga, Leonor Gonçalves de Azevedo e Leonor Rodrigues, uma dona viúva que casou pela segunda vez por desígnio da rainha. Estes casamentos não seriam voluntários, podendo tratar-se de uma estratégia da rainha em unir famílias e linhagens de uma forma que lhe parecesse apropriada ou conveniente.

Exemplo disto foi o casamento de Sancha Andeiro com Álvaro Gonçalves organizado pela rainha. O pai da noiva, João Fernandes Andeiro, "privado" dos reis de Portugal e emissário secreto entre D. Fernando e(?) Inglaterra, foi feito Conde de Ourém, estando também ligado à

\footnotetext{
${ }^{31}$ LOPES, Fernão - Crónica de D. Fernando... Vol. I, p. 182.

${ }^{32}$ Idem.
} 
Casa da infanta D. Beatriz, filha dos reis de Portugal. Era casado com uma dona de nome Maior, que terá ido várias vezes à corte portuguesa, onde a rainha Leonor Teles lhe fazia “(...) grande gasalhado, dando-lhe joyas d'ouro e de prata e grandes dadivas de dinheiros"33. Não se pode afirmar que a esposa de João Fernandes Andeiro fizesse parte do séquito da rainha, mas as suas filhas (Sancha, Teresa, Isabel e Inês) poderiam ter pertencido ao grupo de donzelas que estavam junto de D. Leonor à espera de um bom matrimónio. Sabe-se que Sancha foi casada pela rainha com um filho de Gonçalo Vasques de Azevedo, privado do rei.

De acordo com Fernão Lopes, Gonçalo Vasques de Azevedo e sua esposa, Inês Afonso, que faria parte do séquito de D. Leonor Teles, desconfiavam que esta mantinha uma relação amorosa com o Conde Andeiro. Confrontada com estas suspeitas, a rainha ameaçou o casal e Gonçalo Vasques de Azevedo, que recebera mercês e era familiar de D. Leonor (por ser primo co-irmão de sua mãe, Aldonça de Vasconcelos) acabou por ser preso ${ }^{34}$. Ao casar o filho deste casal, Álvaro Gonçalves, com a filha do Conde Andeiro, Sancha, D. Leonor unia as duas famílias, naquilo que poderá ter sido uma tentativa de abafar as desconfianças e rumores sobre a sua relação com Andeiro.

César Oliveira Serrano fala também de uma criada de Leonor Teles, Senhorinha Fernandes do Amaral, a quem D. Fernando fez uma doação, em 1383, do mantimento, vestuário e casas que pertenceram a Urraca Anes, covilheira da infanta D. Beatriz ${ }^{35}$.

\subsection{A infanta D. Beatriz de Portugal}

Em 1373 nasceu D. Beatriz, filha de D. Fernando e D. Leonor. Com o nascimento da infanta, algumas das mulheres que serviam a rainha passaram para a Casa da sua filha, permanecendo, no entanto, sob supervisão de Leonor Teles, que seria a principal responsável por recrutar e gerir as damas que serviam e acompanhavam D. Beatriz.

Algumas destas senhoras foram: Teresa de Meira, uma das donzelas a quem a rainha arranjou casamento, unindo-a a Fernão Gonçalves de Sousa; Iria Gonçalves do Carvalhal, mãe de Nuno Álvares Pereira, que desempenhou a função do covilheira; Violante Afonso, como sua aia e que estivera casada com Diogo Gomes de Abreu; e Maria Afonso de Brito, camareira-mor e esposa de Vasco Martins de Melo.

Como donzelas da sua casa, destacam-se as irmãs Isabel e Beatriz de Castro, filhas de Álvaro Peres de Castro $^{36}$, parentes da rainha e da infanta. Beatriz de Castro terá sido criada pela

\footnotetext{
${ }^{33}$ Idem, p. 60.

${ }^{34}$ LOPES, Fernão - Crónica de D. Fernando... Vol. II, pp. 74-76.

${ }^{35}$ SERRANO, César Oliveira - Beatriz de Portugal. La pugna dinástica Avís-Trastámara. Galiza: Instituto de Estudios Gallegos, 2005. p. 220

${ }^{36}$ Idem, p. 149.
} 
Silva, Mariana Faria da - As mulheres que acompanharam as rainhas de Portugal. Os séquitos femininos de Leonor Teles, Filipa de Lencastre e Leonor de Aragão (1371-1445). In Omni Tempore-Atas dos Encontros da Primavera 2020. Porto: FLUP, 2021. pp. 143-176.

rainha, passando depois para o serviço da sua filha, tendo-a acompanhado a Castela quando esta casou com o rei Juan I.

Além destas mulheres, Isabel de Pina Baleiras menciona Constança Eanes Botelho como ama da infanta e Urraca Eanes como covilheira ${ }^{37}$.

Em Casamentos da Família Real Portuguesa, Ana Maria S. A. Rodrigues indica também Urraca Tenório, irmã do bispo Pedro Tenório de Coimbra, esposa de Aires Gomes da Silva e mãe de Afonso Tenório, como aia da infanta D. Beatriz ${ }^{38}$. Urraca Tenório é também mencionada na obra de Beatriz de Portugal. La pugna dinástica Avís-Trastámara, de César Oliveira Serrano.

Ao casar com o rei Juan I de Castela, a infanta foi acompanhada ao seu novo reino por um grupo de oficiais escolhidos por seu pai, assim como por várias mulheres que compunham o séquito de sua mãe. Pode concluir-se que os soberanos seleccionaram pessoas da sua confiança para acompanhar a filha. Além disso, muitas das mulheres que saíram do gineceu da rainha de Portugal para servir a infanta no seu novo papel como Rainha de Castela, já a poderiam conhecer desde o seu nascimento. Como o seu séquito era composto por mulheres que serviram a sua mãe, o gineceu de D. Beatriz poderia simbolizar uma ligação à casa materna.

Verifica-se que a casa de D. Beatriz funcionou como uma continuação da Casa de Leonor Teles. Com efeito, algumas das senhoras que a acompanharam a Castela fizeram parte do séquito feminino de Leonor Teles, como foi o caso de Teresa de Meira, que foi donzela na sua corte e Beatriz de Castro, que terá sido criada pela rainha e passado depois para o serviço da sua filha

Segundo César Oliveira Serrano, D. Beatriz recebeu um património para sustentar a sua própria casa, que, no entanto, continuou sob a supervisão de Leonor Teles. Baseando-se no capítulo XXIX da Monarchia Lusitana, parte VIII, de Manuel dos Santos, o autor informa que Constança Martins Botelho fazia parte da Casa da infanta. A estas juntam-se a covilheira Urraca Anes (falecida em 1383) e a sua aia Violante Afonso, viúva de Diogo Gomes Abreu ${ }^{39}$. O autor fala também da covilheira Iria Gonçalves do Carvalhal, mãe de Nuno Álvares Pereira, que terá sido escolhida devido às suas qualidades ${ }^{40}$. A esposa de Vasco Martins de Melo (copeiro-mor da infanta), cujo nome não conseguimos encontrar, terá sido camareira-mor de D. Beatriz ${ }^{41}$.

\footnotetext{
${ }^{37}$ BALEIRAS, Isabel de Pina - Uma rainha inesperada. Leonor Teles... p. 127.

${ }^{38}$ RODRIGUES, Ana Maria S. A. (dir.) - Casamentos da Família Real Portuguesa. Diplomacia e cerimonial. Lisboa: Círculo de Leitores, 2017. p. 91.

${ }^{39}$ SERRANO, César Oliveira - Beatriz de Portugal. La pugna dinástica Avís-Trastámara ... p. 220.

${ }^{40}$ Idem, p. 221.

${ }^{41} \mathrm{Idem}$.
} 
Silva, Mariana Faria da - As mulheres que acompanharam as rainhas de Portugal. Os séquitos femininos de Leonor Teles, Filipa de Lencastre e Leonor de Aragão (1371-1445). In Omni Tempore-Atas dos Encontros da Primavera 2020. Porto: FLUP, 2021. pp. 143-176.

Estas senhoras terão sido, na opinião de César Oliveira Serrano, as pessoas mais próximas da infanta, entre os quatro e os onze anos ${ }^{42}$. A esposa de Vasco Martins de Melo (copeiro-mor da infanta), cujo nome não conseguimos encontrar, terá sido camareira-mor de D. Beatriz.

\subsection{Regência}

Após a morte do marido, D. Leonor assumiu a regência do reino. Uma conspiração levou ao assassinato de João Fernandes Andeiro. Depois disto, temendo a população, Leonor Teles saiu de Lisboa e foi para Alenquer, e daqui para Santarém, onde Gonçalo Vasques de Azevedo, pai de Leonor Gonçalves de Azevedo (donzela da casa da Rainha), era alcaide, e onde entrou no início de 1384. Do séquito que acompanhou Leonor Teles a estes locais, constavam João Afonso Pimentel e Martim Gonçalves de Ataíde, pelo que podemos sugerir que a irmã da rainha e esposa do primeiro, Joana Teles, também estaria presente, bem como a esposa do segundo, Mécia Vasques Coutinho.

Sobre a partida de D. Leonor para Alenquer, Fernão Lopes relata que “(...) partio a Rainha gramde manhãa (...) com Donas e Domzellas quamtas avia em sua casa (...) ${ }^{\sharp 43}$. Perante o clima de instabilidade, o rei de Castela, Juan I, entrou em Portugal, tendo-se dirigido a Santarém, onde estava a sogra, acompanhado por D. Beatriz “(...) a quall viinha em cima huua mulla de sella cuberta de doo, e dona Beatriz de Castro, e outras donas e domzellas com ella (...)"44.

Com a leitura da crónica, podemos comprovar a importância das donas e donzelas que acompanhavam e serviam as rainhas, uma vez que o cronista as menciona na partida de Leonor para Alenquer e na entrada de Beatriz em Santarém. Nesta última, é destacada a presença de D. Beatriz de Castro, filha de Álvaro Peres de Castro no séquito da rainha de Castela.

O rei de Castela passou a intitular-se rei de Portugal e Leonor Teles terá sido acusada de querer matar o genro. Descoberta esta conspiração, Juan I de Castela mandou prender a camareira da sogra, Maria Peres, que revelou os alegados planos da rainha viúva ${ }^{45}$. A camareira foi ainda presa e torturada para dizer onde é que Leonor Teles escondera as suas jóias, o que Maria Peres confessou ${ }^{46}$.

Confrontada com esta acusação, Leonor Teles foi desterrada para o Convento de Santa Clara, em Tordesilhas e não terá voltado mais a Portugal. Com ela terão seguido alguns dos seus apoiantes bem como um séquito de senhoras para a servir, não se sabendo, porém, os

\footnotetext{
${ }^{42}$ Idem.

${ }^{43}$ LOPES, Fernão - Crónica de D. João I... Vol. I, p. 37.

${ }^{44}$ Idem, p. 124.

${ }^{45}$ Idem, p. 159-160.

${ }^{46}$ Idem, p. 162.
} 
Silva, Mariana Faria da - As mulheres que acompanharam as rainhas de Portugal. Os séquitos femininos de Leonor Teles, Filipa de Lencastre e Leonor de Aragão (1371-1445). In Omni Tempore-Atas dos Encontros da Primavera 2020. Porto: FLUP, 2021. pp. 143-176.

nomes de quem a acompanhou. Nada mais é dito nas crónicas a respeito de Leonor Teles, que faleceu em data incerta.

Em A Corte dos Reis de Portugal no Final da Idade Média, Rita Costa Gomes diz que nem todas as mulheres que eram próximas de Leonor a acompanharam no exílio, e apresenta duas camareiras cujos nomes não foram encontrados nas fontes consultadas: Mor Afonso e Constança $\mathrm{Anes}^{47}$. A autora fala ainda de Senhorinha Fernandes do Amaral, que terá sido "criada" ou camareira de Leonor Teles, mas nada mais se sabe sobre ela.

\subsection{Damas de D. Leonor Teles}

Começamos com Maria Teles, filha de Martim Afonso Telo e de Aldonça de Vasconcelos e irmã de D. Leonor Teles. Casou com Álvaro Dias de Sousa, senhor de Mafra e Ericeira, com quem teve Lopo Dias de Sousa, Mestre da Ordem de Cristo. D. Maria fazia parte do séquito de D. Beatriz, irmã de D. Fernando, como já foi referido, e pode supor-se que teria continuado na corte junto de sua irmã, quando esta se tornou rainha. Já viúva terá casado com D. João, filho de D. Pedro I e D. Inês de Castro. Fernão Lopes descreve o episódio do assassinato de Maria Teles às mãos de D. João. Devido às suas possibilidades financeiras, D. Maria mantinha o seu próprio séquito, o que mostra que não eram só as rainhas a tê-lo.

Segue-se Joana Teles, filha ilegítima de Martim Afonso Telo e de D. Senhorinha Martins ${ }^{48}$ e irmã de Leonor Teles. Foi comendadeira de Santos e casou com João Afonso Pimentel, com quem teve pelo menos uma filha, D. Beatriz (casada em 1395 com Martim Afonso de Melo ${ }^{49}$ ). Além de ter organizado este casamento, a rainha doou-lhes Bragança. Sendo Comendadeira de Santos, não estava sujeita ao voto de celibato. Não se conhece a sua data e local de nascimento e de morte, mas segundo Isabel de Pina Baleiras, em 1385, D. Joana era ainda viva, vivendo em Castela como primeira Condessa de Benavente ${ }^{50}$. É mencionada na Crónica de D. Fernando, quando o cronista fala nos casamentos arranjados pela rainha. O seu marido surge na Crónica de D. João I, fazendo parte do grupo de fidalgos que acompanhava João Fernandes Andeiro ${ }^{51}$ e como membro da Casa da Rainha, que acompanhou quando esta saiu de Lisboa e se retirou para Alenquer e depois para Santarém, cidade onde João Afonso Pimentel esteve junto do rei de Castela.

\footnotetext{
${ }^{47}$ GOMES, Rita Costa - A Corte dos Reis de Portugal no Final da Idade Média... p. 50.

${ }^{48}$ BALEIRAS, Isabel de Pina - Uma rainha inesperada. Leonor Teles... p. 32.

${ }^{49}$ FREIRE, Anselmo Braamcamp - Brasões da Sala de Sintra. Coimbra: Imprensa da Universidade de Coimbra, 1921. Vol. I, p. 422.

${ }^{50}$ Idem, p. 33.

${ }^{51}$ LOPES, Fernão - Crónica de D. João I... Vol. I, p. 18
} 
Silva, Mariana Faria da - As mulheres que acompanharam as rainhas de Portugal. Os séquitos femininos de Leonor Teles, Filipa de Lencastre e Leonor de Aragão (1371-1445). In Omni Tempore-Atas dos Encontros da Primavera 2020. Porto: FLUP, 2021. pp. 143-176.

Inês Dias Botelho, que segundo Fernão Lopes, era parente de Leonor Teles, e foi donzela da sua Casa. A rainha casou-a com Pedro Rodrigues da Fonseca, tendo doado Olivença aos noivos. Desconhecem-se datas e locais de nascimento e morte. É mencionada como uma das donzelas a quem a rainha arranjou casamento e o marido surge na Crónica de D. João I, sendo membro do grupo de fidalgos que acompanhavam João Fernandes Andeiro ${ }^{52}$, e é também referido aquando da tomada do castelo de Évora, quando alguns dos que o defendiam se refugiaram junto de Pero Rodrigues da Fonseca, alcaide de Olivença.

Segue-se Mécia Vasques Coutinho, filha de Vasco Fernandes Coutinho e de Beatriz Gonçalves de Moura e irmã de Gonçalo Vasques Coutinho, Fernão Martins Coutinho, Teresa Vasques Coutinho e Leonor Vasques Coutinho. O seu casamento com Martim Gonçalves de Ataíde foi arranjado pela rainha, que lhes doou o castelo de Chaves. $\mathrm{O}$ casal teve os seguintes filhos: Álvaro Gonçalves, Vasco Gonçalves, Isabel, Helena, Filipa e Catarina de Ataíde (que foram damas da rainha D. Filipa de Lencastre $)^{53}$. Na Crónica de D. João I, Fernão Lopes conta que durante o cerco a Chaves, D. João, Mestre de Avis, mandava todos os dias um cântaro de água a Mécia ${ }^{54}$. Na obra Brasões da Sala de Sintra, Anselmo Braamcamp Freire também conta este episódio, relatando que “(...) Mecia Vasques, mulher do Alcaide mor, (...) em atenção a ser irmã de Gonçalo Vasques Coutinho, um dos seus capitães, consentia el Rei se lhe mandasse todos os dias um cântaro de boa água (...)"55. Martim Gonçalves de Ataíde, que em 1384 beijara a mão do rei Juan I de Castela ${ }^{56}$, entregou Chaves ao Mestre de Avis em $1386^{57}$ e enviou a esposa e os filhos para Monterrey ${ }^{58}$. Mécia Vasques Coutinho surgirá mais tarde como integrante do séquito de D. Filipa de Lencastre, tendo sido, depois de viúva, aia dos filhos desta rainha e de D. João I ${ }^{59}$.

Também Teresa de Meira, filha de Gonçalo Pais de Meira e irmã de Fernão Gonçalves de Meira, foi casada com Fernão Gonçalves de Sousa pela rainha, que lhes doou Porte ${ }^{60}$. Na Crónica de D. João I é acusada de ter aconselhado o marido a ficar do lado de Castela durante a Crise de $1383-1385^{61}$, visto ter sido aia de D. Beatriz, rainha de Castela. Com a vitória portuguesa acabou por ser expulsa de Portel com o marido, tendo ido para Castela, onde recebera as terras de Safra e Vila Ruiva ${ }^{62}$. Fernão Lopes faz uma descrição insólita da saída do casal de Portel: descrito

\footnotetext{
52 Idem.

${ }^{53}$ FREIRE, Anselmo Braamcamp - Brasões da Sala de Sintra... Vol. I, p. 66.

${ }^{54}$ Idem, p. 164-165.

${ }^{55}$ Idem, Vol. I, p. 78.

${ }^{56}$ Idem, p. 76.

${ }^{57}$ Idem, p. 79.

${ }^{58}$ LOPES, Fernão - Crónica de D. João I... Vol, I, pp. 169-170.

${ }^{59}$ FREIRE, Anselmo Braamcamp - Brasões da Sala de Sintra... Vol. I, p. 106.

${ }^{60}$ LOPES, Fernão - Crónica de D. Fernando I... Vol II, p. 19.

${ }^{61}$ LOPES, Fernão - Crónica de D. João I... Vol, I, pp. 333-334.

${ }^{62}$ Idem, Vol. II, pp. 336-338.
} 
Silva, Mariana Faria da - As mulheres que acompanharam as rainhas de Portugal. Os séquitos femininos de Leonor Teles, Filipa de Lencastre e Leonor de Aragão (1371-1445). In Omni Tempore-Atas dos Encontros da Primavera 2020. Porto: FLUP, 2021. pp. 143-176.

pelo cronista como "o mais saboroso homem que em Portugall avia, e mui sollto em suas palavras (...)", ao ser expulso do seu castelo, Fernão Gonçalves de Sousa ordenou que houvesse música, ao som da qual disse que iria dançar com sua esposa, que culpou pela perda das suas terras ${ }^{63}$.

Beatriz Nunes (de Góis), filha de Nuno Martins de Góis e de Branca do Avelar, foi casada pela rainha com Gonçalo Viegas de Ataíde. A mãe de Beatriz pertenceria à família Avelar, linhagem importante na Casa da rainha D. Beatriz de Castela (mãe de D. Pedro I) ${ }^{64}$.

Sancha Andeiro, filha de João Fernandes Andeiro, teve o seu casamento arranjado pela rainha, que a uniu a Álvaro Gonçalves, filho de Gonçalo Vasques de Azevedo e de Inês Afonso. Após a Batalha de Aljubarrota, na qual morreram o marido e o sogro de Sancha, esta e a sogra foram chamadas à presença de D. João I de Portugal, a quem manifestaram a sua vontade de ir para Castela. Autorizadas a fazê-lo, D. Sancha e Inês Afonso partiram na frota castelhana que se encontrava em Lisboa ${ }^{65}$.

Leonor Gonçalves de Azevedo, filha de Gonçalo Vasques de Azevedo e irmã de Álvaro Gonçalves (e consequentemente cunhada de Sancha Andeiro), foi casada pela rainha com Gonçalo Vasques Coutinho, filho de Vasco Fernandes Coutinho. Na Crónica de D. Fernando, quando Fernão Lopes fala nos casamentos organizados por Leonor Teles, Leonor é apenas referida como “(...) uma filha de Gonçalo Vasques de Azevedo (...)" "66, sendo possível conhecer o seu nome através da leitura da primeira parte da Crónica de D. João I, onde ela aparece junto do marido num jantar que este organizou para outros fidalgos com quem andava desavindo. Leonor aparece feliz com a reconciliação ${ }^{67}$.

Leonor Rodrigues, de filiação desconhecida, casou duas vezes: a primeira com João Fernandes Cogominho e a segunda com Paio Rodrigues Marinho, num casamento arranjado por D. Leonor Teles. Do primeiro casamento nasceu pelo menos uma filha, Beatriz Fernandes Cogominho. Na Crónica de D. Fernando, Leonor é apenas mencionada como “( ...) mulher que foi de João Fernandes

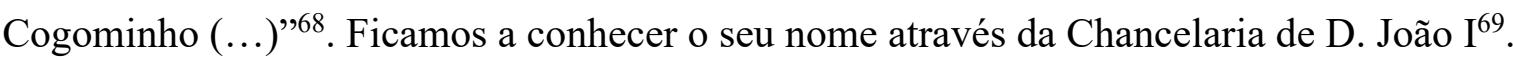

Iria Gonçalves do Carvalhal, a mãe de Nuno Álvares Pereira e de Fernão, Rodrigo, Vasco, João e Gonçalo Pereira, irmã de Martim Gonçalves Carvalhal, fez também parte da Casa da rainha. Natural de Elvas, foi, segundo Fernão Lopes “(...) mui nobre dona (...), vivendo em grande castidade e abstinençia, fazemdo muitas esmollas e gramdes jejuns, nom comendo carne

\footnotetext{
${ }^{63}$ Ibidem.

${ }^{64}$ GOMES, Rita Costa - A Corte dos Reis de Portugal no Final da Idade Média ... pp. 48-50.

${ }^{65}$ LOPES, Fernão - Crónica de D. João I... p. 136.

${ }^{66}$ LOPES, Fernão - Crónica de D. Fernando... Vol. II, p. 19.

${ }^{67}$ LOPES, Fernão - Crónica de D. João I... Vol I, pp. 43-45.

${ }^{68}$ LOPES, Fernão - Crónica de D. Fernando... Vol. II, p. 19.

${ }^{69}$ Chancelaria de D. João I (1385-1433). Ed. de João Alves Dias, Lisboa: Lisboa: Centro de Estudos Históricos da U.N.L., 2004. Tomo II, Vol. 3, p. 245.
} 
Silva, Mariana Faria da - As mulheres que acompanharam as rainhas de Portugal. Os séquitos femininos de Leonor Teles, Filipa de Lencastre e Leonor de Aragão (1371-1445). In Omni Tempore-Atas dos Encontros da Primavera 2020. Porto: FLUP, 2021. pp. 143-176.

nem bevendo vinho per espaço de quarenta annos"70. Tentou demover o filho de servir o Mestre de Avis, mas acabou por concordar com a sua decisão, dando-lhe a sua bênção ${ }^{71}$.

Maria Peres, que ocupou o cargo de camareira-mor de D. Leonor Teles. Foi aprisionada e torturada por ordem do rei de Castela, Juan I, para que dissesse o que sabia sobre os alegados planos de conspiração da rainha e o local onde esta escondera as suas jóias ${ }^{72}$.

As filhas de Álvaro Pires de Castro e de Maria Ponce de Leão, e sobrinhas de D. Inês de Castro, Beatriz e Isabel, também integraram o séquito de D. Leonor Teles.

Beatriz de Castro casou com o conde de Maiorgas, D. Pedro de Lara. Na Crónica de D. João I, Fernão Lopes descreve um diálogo entre ela e o infante D. Afonso Henriques, meio- irmão do rei de Castela, e seu pretendente, no qual ela diz ter sido criada por D. Leonor Teles, que a colocou ao serviço da sua filha, D. Beatriz, tendo-a acompanhado a Castela. Nesta conversa, Beatriz de Castro mostra-se preocupada com o futuro da rainha e sugere ao infante D. Afonso Henriques que este proponha ao seu irmão ajudar Leonor Teles, libertando-a do rei de Castela e podendo os dois casar e ficar como regentes de Portugal. Afonso Henriques, que pretendia casar com D. Beatriz, concordou com ela e falou ao irmão, que aceitou a proposta ${ }^{73}$. Na tentativa de ajudar a sua rainha, D. Beatriz poderá ter instigado uma alegada conspiração contra Juan I de Castela, que levou à prisão a camareira de Leonor Teles e da própria rainha-viúva num convento em Castela. Beatriz de Castro é também mencionada como tendo integrado o séquito de D. Beatriz, rainha de Castela, quando esta entrou em Santarém ${ }^{74}$. Fernão Lopes também descreveu o seu casamento com o Conde de Maiorgas ${ }^{75}$. Aparece depois mencionada como uma das mulheres designadas por D. João I, rei de Portugal, para constituir a casa de sua esposa, D. Filipa de Lencastre $^{76}$, e a ela nos voltaremos a referir.

Isabel de Castro, casou com D. Pedro. Fernão Lopes descreve o convite feito por Isabel de Castro ao seu primo co-irmão, D. João de Castro, e diz que ela era "moradora" da rainha ${ }^{77}$. Também Anselmo Braamcamp Freire, na sua obra, Brasões da Sala de Sintra, descreve este jantar:

[D. João de Castro] jantou com o cunhado, com a sua prima D. Isabel de Castro, dama da rainha e filha do Conde de Arraiolos, sendo em ambos estes convites tratado com grande magnificência e júbilo. D. Isabel, como senhora de extremada beleza, tinha muitos admiradores entre os fidalgos (...), distinguindo-se (...) D. João Afonso ${ }^{78}$, muito seu apaixonado. Todos se apresentaram na festa em que se folgou e dançou (...). Da casa de D.

\footnotetext{
${ }^{70}$ LOPES, Fernão - Crónica de D. João I... p. 66.

${ }^{71}$ Idem, pp. 76-77.

${ }^{72}$ LOPES, Fernão - Crónica de D. João I... Vol I, pp. 158-162.

${ }^{73}$ Idem, pp. 151-152.

${ }^{74}$ Idem, p. 124.

${ }^{75}$ Idem, p. 287.

${ }^{76}$ Idem, Vol. II, p. 224-225.

${ }^{77}$ LOPES, Fernão - Crónica de D. Fernando... pp. 149-150.

78 Trata-se de D. João Afonso Telo, irmão de D. Leonor Teles.
} 
Silva, Mariana Faria da - As mulheres que acompanharam as rainhas de Portugal. Os séquitos femininos de Leonor Teles, Filipa de Lencastre e Leonor de Aragão (1371-1445). In Omni Tempore-Atas dos Encontros da Primavera 2020. Porto: FLUP, 2021. pp. 143-176.

Isabel de Castro, dirigiram-se as donas e as donzelas, cavaleiros e escudeiros, em luzida comitiva ao paço, onde alegremente foram recebidos $(\ldots)^{\text {")79 }}$.

Elvira, integrava a Casa de Leonor Teles, que a terá apontado como verdadeira mãe de Álvaro da Cunha (ou de Sousa), sendo o pai Lopo Dias de Sousa, quando na realidade, Álvaro era filho de Leonor e do seu marido João Lourenço da Cunha ${ }^{80}$. Esta mulher serviria Leonor Teles antes de esta se ter tornado rainha e poderá ter continuado no seu séquito.

Inês Afonso, mulher de Gonçalo Vasques de Azevedo, com quem teve Álvaro Gonçalves, perdeu o marido e o filho, que lutavam por Castela, na Batalha de Aljubarrota e partiu com a nora, Sancha Andeira, que já mencionamos, para Castela.

Do séquito de D. Leonor fez também parte uma filha do arcebispo de Braga, casada pela rainha com Fernão Gonçalves de Moura. A historiografia apresenta-a como Branca Lourenço ${ }^{81}$.

Na primeira parte da Crónica de D. João I, Fernão Lopes fala em Martim Afonso Arnalho, mercador e juiz em Évora, casado com uma donzela (cujo nome não é mencionado) da Casa da rainha D. Leonor Teles ${ }^{82}$.

\section{D. Filipa de Lencastre}

D. Filipa de Lencastre nasceu em Inglaterra, sendo a primogénita de João de Gante, filho do rei inglês Eduardo III e de Branca de Lencastre, e entre os seus irmãos encontrava-se o futuro rei Henrique $\mathrm{IV}^{83}$. Casou em 1387, na Sé do Porto, com o rei de Portugal D. João I e, segundo Fernão Lopes, logo a seguir ao casamento, o rei “ordenou (...) casa a rainha e certa remda pêra sua despesa (...)” enquanto não recebesse “(...) terras por guovernamça de sua pessoa e estado (...) $)^{, 84}$, como fora prometido.

\subsection{Séquito inglês}

Tendo em conta que as futuras consortes chegavam aos seus novos reinos acompanhadas por um grupo de pessoas oriundas da sua terra natal, podemos afirmar que D. Filipa chegou a Portugal com um séquito inglês, composto por clérigos, cortesãos e damas.

Segundo Manuela Santos Silva, William J. Entwistle e Peter E. Russell eram de opinião que a rainha trouxe consigo um grupo de oficiais ingleses, que permaneceram consigo mesmo depois do casamento. No entanto, apenas mencionam uma donzela inglesa que terá vindo para Portugal com D. Filipa, chamada Elizabeth Elmhan, que surge como portadora de uma carta

\footnotetext{
${ }^{79}$ FREIRE, Anselmo Braamcamp - Brasões da Sala de Sintra... Vol. I, p. 92.

${ }^{80}$ LOPES, Fernão - Crónica de D. João I... Vol. I, p. 396.

${ }^{81}$ GOMES, Rita Costa - A Corte dos Reis de Portugal no Final da Idade Média ... p. 50.

${ }^{82}$ LOPES, Fernão - Crónica de D. Fernando... Vol. I, p. 88.

${ }^{83}$ SILVA, Manuela Santos - A rainha inglesa de Portugal. Filipa de Lencastre... p. 21.

${ }^{84}$ LOPES, Fernão - Crónica de D. João I... Vol. II, pp. 224-225.
} 
Silva, Mariana Faria da - As mulheres que acompanharam as rainhas de Portugal. Os séquitos femininos de Leonor Teles, Filipa de Lencastre e Leonor de Aragão (1371-1445). In Omni Tempore-Atas dos Encontros da Primavera 2020. Porto: FLUP, 2021. pp. 143-176.

enviada pela rainha ao bispo de Norwich. Elizabeth terá regressado a Inglaterra, sem ter conseguido arranjar um casamento vantajoso em Portugal ${ }^{85}$.

Fernão Lopes não fala em nenhum oficial inglês, mas na Crónica de D. João I, menciona uma filha de Fernando Afonso de Albuquerque, Mestre de Santiago, chamada Joana de Albuquerque, cuja mãe era inglesa e que terá sido colocada na corte portuguesa por D. João $\mathrm{I}^{86}$. Podemos supor que a menina, de origem inglesa, tivesse sido colocada ao serviço da rainha.

\subsection{A Casa da rainha de Portugal}

Na segunda parte da Crónica de D. João I, Fernão Lopes apresenta o nome de sete das mulheres que D. João I encarregou de servir, acompanhar e ensinar os costumes portugueses à rainha, como foi o caso da aia Beatriz Gonçalves de Moura ${ }^{87}$. Não se sabe se a iniciativa para escolher estas senhoras terá partido mesmo do rei ou da sugestão de terceiros. Uma análise das famílias a que estas senhoras pertenciam permite-nos concluir que os membros de linhagens que se mantiveram junto de D. João I durante a Crise de 1383-1385, foram seleccionadas para integrar o gineceu da nova rainha. O papel desempenhado por Beatriz Gonçalves de Moura foi muito importante para a rainha, principalmente nos primeiros tempos de casada, visto que, enquanto inglesa, D. Filipa não conheceria os hábitos portugueses.

A Casa de D. Filipa volta a ser mencionada nesta crónica quando o cronista fala nas quantias ("moradias") que as mulheres da sua Casa deviam receber: Beatriz de Castro, a donzela de mais alta estirpe (que já fizera parte do séquito de Leonor Teles e depois da infanta D. Beatriz), recebia 1000 libras mensais; Beatriz Gonçalves de Moura, enquanto aia da rainha, recebia 800 libras; a sua filha Teresa Vasques Coutinho, camareira-mor, tinha direito a 200 libras por mês. As camareiras ao serviço da rainha tinham, mensalmente, $60 \operatorname{libras}^{88}$.

Verifica-se que o gineceu de Filipa de Lencastre era composto por senhoras da mesma família. Exemplo disso é o caso de Beatriz Gonçalves de Moura, suas filhas, Teresa Vasques Coutinho (camareira-mor), Leonor Vasques e Mécia Vasques (donzela casada por D. Leonor Teles) ${ }^{89}$ e suas netas, Filipa e Catarina de Ataíde (damas de D. Filipa de Lencastre e filhas de Mécia Vasques) ${ }^{90}$.

Além destas, estavam ainda presentes no séquito da rainha as irmãs Leonor e Beatriz Pereira, bem como Berengária Nunes Pereira, todas elas familiares de Nuno Álvares Pereira ${ }^{91}$.

\footnotetext{
${ }^{85}$ SILVA, Manuela Santos - A rainha inglesa de Portugal. Filipa de Lencastre... p. 182.

${ }^{86}$ LOPES, Fernão - Crónica de D. João I... p. 214.

${ }^{87}$ Idem, Vol. 2, pp. 224-225.

${ }^{88}$ SILVA, Manuela Santos - A rainha inglesa de Portugal. Filipa de Lencastre... p. 185.

${ }^{89}$ Idem, p 183.

${ }^{90}$ BRAANCAMP, Anselmo Freire - Brasões da Sala de Sintra ... p. 80.

${ }^{91}$ LOPES, Fernão - Crónica de D. João I... Vol II, p. 225.
} 
Silva, Mariana Faria da - As mulheres que acompanharam as rainhas de Portugal. Os séquitos femininos de Leonor Teles, Filipa de Lencastre e Leonor de Aragão (1371-1445). In Omni Tempore-Atas dos Encontros da Primavera 2020. Porto: FLUP, 2021. pp. 143-176.

Verifica-se também que algumas destas mulheres, depois de terem servido D. Leonor Teles e a sua filha, passaram para o serviço de D. Filipa de Lencastre, como foi o caso de Beatriz de Castro.

Manuela Santos Silva acrescenta ainda a aia Maria Vasques, D. Catarina, D. Briolanja e D. Beatriz de Melo, mas nada mais se sabe sobre estas mulheres ${ }^{92}$. A estas se juntam as senhoras indicadas por Rita Costa Gomes: Isabel Fernandes de Moura, Catarina Vasques de Ataíde, Maria da Cunha, Maria Resende, Catarina Teixeira, Inês do Casal, Leonor Leitão, Margarida Martins Miranda (filha do arcebispo de Braga, Martim Afonso da Charneca), Catarina Fernandes de Barros, Beatriz Afonso Goriza e a esposa de Gonçalo Anes Penteado ${ }^{93}$.

A leitura da chancelaria permitiu conhecer duas senhoras que estiveram ao serviço da rainha D. Filipa: Inês Rodrigues, ama do infante D. Duarte e Isabela Sanches, ama do infante D. Afonso ${ }^{94}$. Ficamos também a conhecer Margarida Esteves, regueifeira da rainha ${ }^{95}$. A chancelaria fala ainda de D. Leonor Gonçalves de Moura, filha de Álvaro Gonçalves de Moura e esposa de Gil Vasques da Cunha ${ }^{96}$, que é também mencionada por Rita Costa Gomes ${ }^{97}$.

Mas como seria esta mudança de casa? Não tendo encontrado nada na bibliografia e nas fontes consultadas, podemos supor que as mulheres eram seleccionadas para constituir a Casa de uma nova rainha pelo apoio prestado pelas suas famílias ou pelo papel desempenhado junto da Coroa.

\subsection{A Infanta D. Isabel}

D. Filipa de Lencastre faleceu em 1415, e com a sua morte, a sua filha, a infanta D. Isabel, tornou-se no elemento feminino mais importante da corte de seu pai, ocupando um lugar central, que pertencera a sua mãe, no gineceu, verificando-se uma continuidade da Casa da Rainha. Com efeito, Beatriz Gonçalves de Moura, aia de D. Filipa, passou para o serviço da infanta. Esta situação durou treze anos, desde o falecimento da rainha, em 1415, até ao casamento do infante D. Duarte, o herdeiro do trono, com D. Leonor de Aragão, em 1428.

Na sua Crónica da Tomada de Ceuta, Gomes Eanes de Zurara conta como a rainha, pouco tempo antes da sua morte, falou com o infante D. Duarte "(...) e lhe emcomemdou os Iffamtes seus jrmaãos e Briatiz Gomçallvez de Moura e Meçia Vaaz sua filha, e assy todallas outras suas cousas (...)"98 . O cronista lembra ainda que o Infante D. Pedro pediu à Rainha que deixasse as suas terras à infanta $\mathrm{D}$. Isabel ${ }^{99}$.

\footnotetext{
${ }^{92}$ SILVA, Manuela Santos - A rainha inglesa de Portugal. Filipa de Lencastre... p. 183.

${ }^{93}$ GOMES, Rita Costa - A Corte dos Reis de Portugal no Final da Idade Média... p. 52.

${ }^{94}$ Chancelaria de D. João I... Vol. 3, tomo II [654], p. 180.

${ }^{95}$ Chancelaria de D. João I... Vol. 1, tomo III [401], p. 214.

${ }^{96}$ Chancelaria de D. João I... Vol. 3, tomo II [925], p. 79.

${ }^{97}$ GOMES, Rita Costa - A Corte dos Reis de Portugal no Final da Idade Média ... p. 52.

${ }^{98}$ ZURARA, Gomes Eanes - Crónica da Tomada de Ceuta... p. 131.

${ }^{99}$ Idem, pp. 132-134.
} 
Silva, Mariana Faria da - As mulheres que acompanharam as rainhas de Portugal. Os séquitos femininos de Leonor Teles, Filipa de Lencastre e Leonor de Aragão (1371-1445). In Omni Tempore-Atas dos Encontros da Primavera 2020. Porto: FLUP, 2021. pp. 143-176.

\subsection{Damas do séquito de D. Filipa}

As linhas seguintes serão dedicadas a senhoras que serviram D. Filipa de Lencastre e que conseguimos encontrar com a leitura da Crónica de D. João I e da Chancelaria do mesmo rei.

Começamos por Beatriz Gonçalves de Moura, filha de Gonçalo Vasques de Moura e de Inês Alvares, viúva de Vasco Fernandes Coutinho e mãe de Teresa Vasques Coutinho, Leonor Vasques Coutinho, Mécia Vasques Coutinho, Gonçalo Vasques Coutinho e Fernão Martins Coutinho. Durante a Crise de 1383-1385, Fernão Lopes conta que Beatriz convenceu o filho, Gonçalo, alcaide de Trancoso e Lamego, a não entregar os seus castelos ao rei de Castela ${ }^{100}$. O rei de Portugal coloca-a ao serviço da sua esposa, D. Filipa de Lencastre, como sua aia, devendo-lhe ensinar os costumes portugueses e da corte ${ }^{101}$. Beatriz Gonçalves de Moura encontrava-se junto da rainha quando o rei lhe disse que ia partir para Ceuta, na ocasião da conquista desta praça ${ }^{102}$. Filipa de Lencastre recomendou-a (e às restantes damas que a serviam) a seu filho D. Duarte.

Também as filhas de Beatriz Gonçalves de Moura e de Vasco Fernando Coutinho, Teresa, Mécia e Leonor, estiveram ao serviço de D. Filipa.

Teresa Vasques Coutinho foi colocada ao serviço de D. Filipa de Lencastre como sua camareira-mor por D. João I e casou com D. Martinho, filho de D. Gonçalo Teles (irmão de Leonor Teles), com quem terá tido Beatriz de Meneses (aia da rainha D. Isabel, esposa de D. Afonso V) ${ }^{103}$.

Mécia Vasques Coutinho, já mencionada, pertencera ao grupo de donzelas casadas por D. Leonor Teles, integrando depois o séquito da rainha inglesa.

Leonor Vasques Coutinho foi também uma das senhoras que serviram D. Filipa de Lencastre.

Beatriz de Castro, filha de Álvaro Peres de Castro, foi já mencionada como donzela ao serviço de Leonor Teles. D. João I colocou-a ao serviço de D. Filipa, enquanto donzela da mais alta estirpe ${ }^{104}$. Em consequência do escândalo que envolveu o seu romance com Fernando Afonso, camareiro do rei, Beatriz foi para Castela, enquanto Fernando foi executado ${ }^{105}$. Fernando Afonso pediu ao rei que lhe desse licença para fazer uma peregrinação a Santa Maria de Guadalupe, mas passou esses dias nos aposentos de Beatriz de Castro. D. João I desconfiou disto e quando os boatos cresceram, expulsou o camareiro da sua Casa. Fernando Afonso, no entanto, em vez de abandonar o paço, refugiou-se nos aposentos de D. Beatriz. O rei mandou chamá-lo à sua

\footnotetext{
${ }^{100}$ LOPES, Fernão - Crónica de D. João I... Vol. I, pp. 116-117.

101 Idem, Vol. II, p. 225.

102 ZURARA, Gomes Eanes - Crónica da Tomada de Ceuta... pp. 119-120.

103 SOUSA, António Caetano - História Genealógica da Casa Real Portuguesa. [Em Linha] Lisboa Ocidental: Na Officina de Joseph Antonio da Sylva, 1735-1749.

104 LOPES, Fernão - Crónica de D. João I... Vol. II, p. 225.

105 Idem, pp. 301-303.
} 
presença e ordenou a sua prisão, mas Fernando Afonso fugiu e refugiou-se numa igreja. Ao saber deste incidente, o próprio monarca dirigiu-se à igreja, onde o camareiro se abraçara a uma imagem no altar, e ordenou que o levassem dali. Fernando Afonso e D. Beatriz alegaram serem casados, mas D. João I mandou que o executassem. Apesar das súplicas da rainha e de outras pessoas, o rei foi inflexível, e Fernando Afonso foi queimado vivo. Beatriz de Castro pensou que também seria executada, mas foi enviada para Castela ${ }^{106}$.

As irmãs Beatriz Pereira e Leonor Pereira, filhas de Álvaro Pereira e irmã de Leonor Pereira estiveram também ao serviço de D. Filipa. Beatriz Pereira casou com Martim Vasques de Resende por ordem do rei, que não consultou os noivos nem as suas famílias ${ }^{107}$ (prática de D. Fernando e D. Leonor Teles também foram acusados) e Leonor Pereira, casou com Gomes Freire.

Beatriz seria mais velha que Leonor, pois quando o seu pai faleceu, D. João I fez mercê das terras da Coroa detidas pelo seu pai a João Álvares Pereira (irmão de Leonor e Beatriz), para ele e seus descendentes. No caso de não ter descendência, as terras passariam para Beatriz e, na ausência de herdeiros desta, passariam para Leonor ${ }^{108}$. Eram ambas familiares de Nuno Álvares Pereira.

A estas junta-se Berengária Nunes Pereira, filha de Rui Pereira e prima de Beatriz e Leonor Pereira. D. João I arranjou o seu casamento com Afonso Vasques Correia sem consultar os noivos ou as suas famílias. Era, também ela, familiar de Nuno Álvares Pereira.

Joana de Albuquerque, era filha de Fernando Afonso de Albuquerque, mestre de Santiago e de uma dama inglesa. Quando Fernando Afonso, embaixador em Inglaterra, regressou destas paragens, trouxe a filha consigo, e com a sua morte, D. João I colocou-a na sua corte ${ }^{109}$. Foi a segunda esposa de Gonçalo Vasques Coutinho, com quem teve uma única filha: Isabel Coutinho ${ }^{110}$.

A estas juntam-se Inês Rodrigues, mulher de Afonso Gonçalves, ama do infante D. Duarte, e Isabela Sanches, viúva de Rodrigo Afonso, vassalo do rei, e ama do infante D. Afonso.

\section{D. Leonor de Aragão}

Leonor era filha do rei Fernando I de Aragão e de Leonor Urraca de Castela. Entre os seus irmãos estavam o rei Alfonso V de Aragão e da Sicília, Juan II, rei de Navarra e Aragão e Maria, rainha consorte de Castela. Em 1428 casou com D. Duarte, herdeiro ao trono português, tendo-se tornado na mulher mais importante da corte, enquanto futura rainha consorte.

\footnotetext{
${ }^{106}$ Idem, pp. 300-303.

107 Ibidem.

${ }^{108}$ BRAANCAMP, Anselmo Freire - Brasões da Sala de Sintra ... Vol. I, pp. 310-311

${ }^{109}$ LOPES, Fernão - Crónica de D. João I... Vol. II, pp. 300-303.

${ }^{110}$ BRAANCAMP, Anselmo Freire - Brasões da Sala de Sintra ... p. 54.
} 
Silva, Mariana Faria da - As mulheres que acompanharam as rainhas de Portugal. Os séquitos femininos de Leonor Teles, Filipa de Lencastre e Leonor de Aragão (1371-1445). In Omni Tempore-Atas dos Encontros da Primavera 2020. Porto: FLUP, 2021. pp. 143-176.

\subsection{Infanta}

Enquanto mulher do infante herdeiro, D. Leonor passava a ser o elemento feminino mais influente da corte, substituindo a cunhada, D. Isabel, neste cargo. D. Filipa de Lencastre, a esposa do rei D. João I, já tinha falecido, pelo que fora a sua filha quem ficara responsável pelo gineceu da corte, como atrás mencionámos.

D. Leonor terá chegado acompanhada por um grupo de mulheres oriundas do seu reino de origem, Castela, entre as quais estaria presente a castelhana Constança de Tovar, sua camareira-mor, viúva de Rui Lopes d'Avalos, condestável de Castela e cujos serviços D. Leonor terá sido aconselhada a dispensar pelo irmão, o rei Alfonso V de Aragão, visto que a sua presença na corte poderia originar alguns problemas na corte portuguesa ${ }^{111}$.

Segundo Ana Maria S. A. Rodrigues, as pessoas que acompanhavam D. Leonor deveriam ser bem acolhidas e não podiam ser afastadas sem o consentimento da infanta ${ }^{112}$. Não se sabe, no entanto, quem eram estas pessoas.

Como camareira, Ana Maria S. A. Rodrigues indica o nome de Catarina Lourenço, que terá sido recompensada pelo rei $\mathrm{D}$. Afonso $\mathrm{V}$, filho de Leonor de Aragão e que a terá acompanhado no exílio em Castela ${ }^{113}$.

Das servidoras de D. Leonor destaca-se também uma parteira, Catarina Afonso, moradora em Évora, que entregou o seu sobrinho, Pedro Eanes, para ser moço de estrebaria da rainha ${ }^{114}$. Com efeito, D. Leonor de Aragão terá sido a primeira rainha a ter uma parteira entre as suas servidoras ${ }^{115}$.

\subsection{Rainha}

Em 1433, com a morte de D. João I, D. Duarte e a esposa tornam-se reis de Portugal. Não se sabe em que medida é que a passagem de infanta para rainha afetou o gineceu da corte, pois enquanto mulher do infante herdeiro, D. Leonor era já a mulher mais importante (D. Filipa de Lencastre tinha já falecido em 1415 e a infanta D. Isabel, irmã de D. Duarte, casara em 1430 com o duque da Borgonha). No entanto, podemos supor que terá aumentado e que mais senhoras se terão juntado ao séquito.

Os nomes dos servidores de D. Leonor são conhecidos através da historiografia. Ana Maria S. A. Rodrigues indica como donzelas Beatriz do Quintal (que, curiosamente, seria de

\footnotetext{
${ }^{111}$ RODRIGUES, Ana Maria S. A. - As tristes rainhas. Leonor de Aragão e Isabel de Coimbra ... pp. 160-161.

112 Idem, p. 56.

${ }^{113}$ Idem, p. 161.

${ }^{114}$ Idem, p. 167.

${ }^{115}$ GOMES, Rita Costa - A Corte dos Reis de Portugal no Final da Idade Média ... p. 57.
} 
origem modesta, filha de Fernando Afonso de Bragança, escrivão das sisas régias e morador em Alhos Vedros), Filipa de Vasconcelos (filha de Gonçalo Mendes de Vasconcelos, e a quem foi prometido um dote para o seu casamento com Vasco de Gouveia, monteiro-mor do rei de Aragão), Grimanesa de Melo (que recebeu um dote para casar com Mem de Brito), Isabel da Silveira (filha de Nuno Martins da Silveira, escrivão da puridade de D. Duarte e sobrinha do bispo de Évora, D. Álvaro e que recebeu um dote para desposar João de Melo), e Teresa de Albuquerque (que terá casado com Luís Álvares) ${ }^{116}$.

Estas donzelas eram, na sua maioria, filhas de figuras importantes das cortes de D. João I e de D. Duarte e casaram com homens que se distinguiram junto de D. Afonso V (filho de Leonor de Aragão) ${ }^{117}$.

D. Leonor tinha também a seu cargo as criadas, como Isabel de Góis e Leonor de Tovar, que recebeu um dote para desposar Pedro Lopes do Quintal, de filiação desconhecida, cavaleiro da casa de D. Afonso ${ }^{118}$.

Como servidoras, Ana Maria S. A. Rodrigues destacou Mor Gonçalves Peixoto e como escrava, uma moura, de nome Margarida. Destaque também para uma "Leonor anaa", que poderia ser uma anã, com a função de distrair a rainha e as suas damas com danças e acrobacias $^{119}$. Como guarda-roupa, surge o nome de Isabel Rodrigues ${ }^{120}$.

\subsection{Regente}

Em 1438, com a morte de D. Duarte, D. Leonor, a rainha viúva, tornou-se regente, mas vivia-se um clima de instabilidade no reino que a opunha ao infante D. Pedro, seu cunhado.

Através da leitura da Crónica de D. Afonso V, de Rui de Pina, sabe-se que D. Leonor terá expulsado de sua casa duas irmãs, filhas de Isabel Gomes da Silva e sobrinha de Aires da Silva, por suspeitar que estas tinham uma aliança com o infante D. Pedro. Esta expulsão causou escândalo, pois as irmãs pertenciam a duas importantes famílias da nobreza de Lisboa ${ }^{121}$. O mesmo aconteceu com uma filha de João Vaz de Almada ${ }^{122}$. D. Leonor acabou por fugir de Almeirim para o Crato, e consigo partiram Maria Dias, sua covilheira, Beatriz Corella, donzela aragonesa; e a ama que criava a filha mais nova de D. Leonor, a infanta D. Joana ${ }^{123}$.

\footnotetext{
${ }^{116}$ RODRIGUES, Ana Maria S. A. - As tristes rainhas. Leonor de Aragão e Isabel de Coimbra... p. 161-167.

${ }^{117}$ Idem, p. 166.

${ }^{118}$ Idem, p. 167.

${ }^{119}$ Idem, p. 161.

${ }^{120}$ Idem, p. 369.

${ }^{121}$ PINA, Rui de - Crónica de D. Afonso V. Lisboa: Escriptorio, 1904. (Biblioteca de Clássicos Portugueses). Vol. I, p. 48.

${ }_{122}$ Idem.

${ }^{123}$ Idem, p. 130.
} 
Silva, Mariana Faria da - As mulheres que acompanharam as rainhas de Portugal. Os séquitos femininos de Leonor Teles, Filipa de Lencastre e Leonor de Aragão (1371-1445). In Omni Tempore-Atas dos Encontros da Primavera 2020. Porto: FLUP, 2021. pp. 143-176.

\subsection{Exílio e morte em Castela}

Perante as ameaças e a instabilidade que se vivia em Portugal, a rainha acabou por se refugiar em Castela, em 1440, e com ela foram Maria Dias (identificada também com Maria Díaz de Almazan) e provavelmente a ama da infanta D. Joana, sua filha, que levou consigo. D. Isabel de Meneses foi também umas das pessoas que acompanhou D. Leonor no exílio, assim como Maria de Vasconcelos e a sua família.

Em Portugal deixou os filhos, o rei D. Afonso V, o infante D. Fernando, a infanta D. Catarina e a infanta D. Leonor, que entregou aos cuidados de D. Guiomar de Castro, aia desta infanta até ao seu casamento. Francisco da Fonseca Benevides, em Rainhas de Portugal, fala em D. Guiomar de Castro, condessa de Atouguia e mulher do conde Álvaro Gonçalves de Ataíde, como aia da infanta D. Leonor ${ }^{124}$. Como vimos, as crianças estavam ligadas ao gineceu da rainha, e as mulheres que as serviam estavam dependentes da soberana. Assim, podemos considerar D. Guiomar de Castro como pertencente ao séquito de D. Leonor de Aragão.

Em Castela, D. Leonor terá passado por dificuldades financeiras, tendo sido ajudada por Maria da Silva, uma dona viúva, que ainda que não tenha feito parte da Casa de Leonor enquanto rainha de Portugal, foi sem dúvida importante nesta fase da sua vida ${ }^{125}$.

Entre o exílio de D. Leonor em Castela, em 1440 e a constituição da Casa de D. Isabel, em 1447 (filha do Infante D. Pedro e rainha de Portugal através do seu casamento com D. Afonso V), verificou-se uma cisão no gineceu cortesão, pois parte das mulheres que serviram D. Leonor foram com ela para Castela e outras permaneceram em Portugal.

Com a morte de D. Leonor, em 1445, os servidores que a seguiram ficaram desamparados, “(...) subitamente desprovidos de sustento e proteção, e abandonados em terra estranha"126, assim como a sua filha, a infanta D. Joana. Ao saber da morte da rainha viúva em Toledo, o infante D. Pedro, seu cunhado, e regente durante a menoridade de D. Afonso V:

(...) enviou logo pela Infante D. Joana, que (...) estava em Toledo em grande desamparo, e a foi ao extremo receber, e trouxe mui honradamente para Lisboa, onde a poz em companhia da Infante D. Catharina sua irmã, em poder de Violante Nogueira, e tomou para El-Rei todolos criados que ficaram da Rainha, tirando alguns em que tinha suspeita e descontentamento ${ }^{127}$.

Ana Maria S. A. Rodrigues afirma que o Infante D. Pedro não terá sido o único a preocupar-se com o destino dos portugueses que ficaram ao lado de D. Leonor, e que existem documentos que indicam que os reis de Aragão (o irmão e a cunhada da rainha) protegeram e

\footnotetext{
${ }^{124}$ BENEVIDES, Francisco da Fonseca - Rainhas de Portugal... p. 191.

${ }^{125}$ PINA, Rui-Crónica de D. Afonso V... Vol. II, cap. LXXXIV, p. 16.

${ }^{126}$ RODRIGUES, Ana Maria S. A. - As tristes rainhas. Leonor de Aragão e Isabel de Coimbra ... p. 237.

${ }^{127}$ PINA, Rui - Crónica de D. Afonso V... Vol. II, cap. LXXXIV, p. 18.
} 
Silva, Mariana Faria da - As mulheres que acompanharam as rainhas de Portugal. Os séquitos femininos de Leonor Teles, Filipa de Lencastre e Leonor de Aragão (1371-1445). In Omni Tempore-Atas dos Encontros da Primavera 2020. Porto: FLUP, 2021. pp. 143-176.

ampararam estas pessoas, colocando-os sob protecção de outros senhores, tendo votado uma especial atenção a quem D. Pedro não aceitou no reino ${ }^{128}$.

Os monarcas de Aragão terão tentado que o infante regente recebesse estas pessoas em Portugal, devolvendo-lhes os cargos e bens que lhes retirara, mas D. Pedro foi inflexível ${ }^{129}$

Muitos servidores foram, com o passar dos anos, pedindo o perdão e o regresso a casa, que foram concedidos, mas só depois da morte do infante D. Pedro na Batalha de Alfarrobeira é que a restauração de elementos do séquito de D. Leonor se intensificou ${ }^{130}$.

Segundo Ana Maria S. A. Rodrigues, em 1450 muitas das criadas da rainha receberam mercês de D. Afonso V. A autora menciona Catarina Sanches, a quem o rei atribuiu uma tença mensal de 3500 reais brancos; Joana Vaz, casada com Diogo de Pedrosa, recebeu uma tença de 2500 brancos, destinada à criação de suas filhas Leonor e Isabel; Leonor Anaa, possivelmente uma anã, que recebeu 1200 reais brancos de tença anual, “(...) mais um moio de trigo, cinco côvados de pano de Bristol e cinco varas de artaniva para mantimento do seu ofício"131. Menciona ainda Leonor Subtil, isentada de “(...) pagar em quaisquer pedidos régios ou concelhios (...)"132 e Aldonça Gonçalves, a quem, em 1471, foi dada uma mercearia em Torres Vedras.

Cerca de três décadas depois do falecimento de D. Leonor, D. Afonso V continuou a recompensar os servidores que se mantiveram junto de sua mãe até à sua morte, não a tendo abandonado mesmo correndo perigo de vida e de verem os seus bens confiscados.

\subsection{Outras damas}

Com base na Chancelaria de D. Afonso V, Ana Maria S. A. Rodrigues incluiu na sua obra sobre Leonor de Aragão um anexo com tabelas que indicam servidoras desta rainha. Não tendo conseguido consultar esta documentação, serão reproduzidos os resultados deste estudo: como criadas, Aldonça Gonçalves (mulher de Afonso de Penela); Catarina Sanches; Isabel de Góis; Joana Vaz (casada com Diogo de Pedrosa); Leonor “Anaa” (possivelmente anã); Leonor Subtil e Leonor de Tovar (donzela da Casa de D. Duarte). Esta última, foi também donzela na sua casa, e a ela se juntam a aragonesa Beatriz (Beatriu) Corella; Beatriz do Quintal; Filipa de Vasconcelos; Grimanesa de Melo; Isabel da Silveira e Teresa de Albuquerque. Maria Afonso surge como ama do infante D. Fernando e Inês Eanes como regueifeira ${ }^{133}$.

\footnotetext{
${ }^{128}$ RODRIGUES, Ana Maria S. A. - As tristes rainhas. Leonor de Aragão e Isabel de Coimbra ... pp. 240-246.

${ }^{129}$ Idem, p. 240.

${ }^{130}$ Idem, pp. 243-244.

${ }^{131}$ Idem, p. 244.

${ }^{132}$ Idem.

${ }^{133}$ Idem, p. 363.
} 
Silva, Mariana Faria da - As mulheres que acompanharam as rainhas de Portugal. Os séquitos femininos de Leonor Teles, Filipa de Lencastre e Leonor de Aragão (1371-1445). In Omni Tempore-Atas dos Encontros da Primavera 2020. Porto: FLUP, 2021. pp. 143-176.

Há também uma tabela sobre a expropriação de bens e instituição de cargos de vários partidários de D. Leonor, como foi o caso de Beatriz Eanes (mulher de Rui Martins, escudeiro do Prior do Crato) e de D. Isabel de Meneses (viúva de D. Fernando de Cascais e casada segunda vez com João Freire de Andrade). D. Isabel foi perdoada e recompensada por D. Afonso V, e tinha acompanhado D. Leonor para Castela, onde foi acusada de ter "praticado homicídios"134.

\subsection{Damas de D. Leonor de Aragão}

Com a leitura da Crónica de D. Afonso V, conseguimos encontrar algumas das senhoras que serviram D. Leonor, e delas se falará nas linhas seguintes.

Maria Dias desempenhou a função de covilheira da rainha. Poderia tratar-se de Maria Díaz de Almazan. Acompanhou D. Leonor quando esta fugiu para o Crato ${ }^{135}$.

Beatriz Corello, donzela de Aragão, acompanhou D. Leonor na sua fuga para o Crato $^{136}$. Não se sabe, no entanto, se a teria acompanhado quando esta chegou a Portugal.

Maria de Vasconcelos, filha de Joane Mendes de Vasconcelos e de Leonor Pereira (filha de Álvaro Gonçalves Pereira, Prior do Hospital) e segunda esposa de D. Afonso, senhor de Cascais e alcaide-mor do castelo de Lisboa, e mãe de D. Fernando de Cascais, que fugiram com a rainha. Foi ela quem tratou da entrega do castelo de Lisboa ao infante D. João (filho de D. João I), tendo recebido oposição do filho, que tentou persuadir o pai a não ceder. D. Afonso entregou o castelo ao infante e foi para junto da rainha, acompanhado pela família, tendo-a acompanhado a Castela. O marido e o filho morreram no exílio, e Maria de Vasconcelos voltou a Portugal quando terminou a regência de D. Pedro, tendo trazido as ossadas do filho. Em gratidão a Maria de Vasconcelos pelos serviços que prestou, o rei D. Afonso V fez-lhe mercê de uma tença de 30000 reais brancos ${ }^{137}$. Pode supor-se que pertenceria à Casa da Rainha, uma vez que a acompanhou na sua fuga ${ }^{138}$.

Isabel Coutinho ou de Meneses, filha única de Pedro de Meneses e de Beatriz Coutinho, casou, antes do desterro, com D. Fernando de Cascais (filho de Maria de Vasconcelos), com quem teve pelo menos um filho, nascido em Castela, para onde foi com o marido e a família. Tendo enviuvado, desposou João Freire de Andrade, senhor de Alcoutim, não tendo havido sucessão deste casamento. Pode considerar-se um elemento da casa da rainha D. Leonor ${ }^{139}$.

\footnotetext{
${ }^{134}$ Idem, pp. 388-393.

${ }^{135}$ PINA, Rui de-Crónica de D. Afonso V... p. 130.

${ }^{136}$ Idem, p. 130.

${ }^{137}$ BRAANCAMP, Anselmo Freire - Brasões da Sala de Sintra ... Vol. I, pp. 352-355.

${ }^{138}$ PINA, Rui de - Crónica de D. Afonso V... p. 131.

${ }^{139}$ BRAANCAMP, Anselmo Freire - Brasões da Sala de Sintra... Vol. I, pp. 352-355.
} 
Silva, Mariana Faria da - As mulheres que acompanharam as rainhas de Portugal. Os séquitos femininos de Leonor Teles, Filipa de Lencastre e Leonor de Aragão (1371-1445). In Omni Tempore-Atas dos Encontros da Primavera 2020. Porto: FLUP, 2021. pp. 143-176.

Maria da Silva de Toledo foi uma dona viúva de Toledo que ajudou D. Leonor, quando esta passava por dificuldades financeiras. Não fez parte da Casa de D. Leonor enquanto rainha de Portugal, mas consideramos justo colocá-la na lista de senhoras que a serviram pelo auxílio que lhe prestou no exílio ${ }^{140}$.

Da Casa de D. Leonor fizeram também parte duas irmãs, donzelas, filhas de Pero Gonçalves, vedor da Fazenda e de Isabel Gomes da Silva, neta de João Gomes da Silva e sobrinha de Aires da Silva. A rainha expulsou ambas da sua Casa, por suspeitar que teriam ligações ao Infante D. Pedro. A expulsão das irmãs, cujos nomes não conseguimos localizar, foi um escândalo, por serem membros de uma importante família de Lisboa ${ }^{141}$.

Uma filha de João Vaz de Almada, cujo nome também não foi possível encontrar, foi também expulsa da Casa da Rainha pelos mesmos motivos das donzelas anteriores ${ }^{142}$.

A estas mulheres junta-se a ama que criava a infanta D. Joana, a filha mais nova de D. Duarte e D. Leonor, e que foi com a rainha para o Crato $^{143}$.

\section{Conclusão}

Ao longo da elaboração deste artigo, surgiram algumas dúvidas, às quais se tentou responder. Uma dessas questões prende-se com a passagem de um séquito para outra senhora e de que forma era feita essa transferência. Como vimos, em caso de inexistência de uma rainha, o gineceu ficava a cargo da mulher mais próxima ao rei, como uma irmã ou uma filha do mesmo. No entanto, quando o rei ou o herdeiro ao trono casavam, a sua esposa passava a ter as mulheres da corte junto a si. Vimos estes casos com D. Beatriz, filha de D. Pedro I, e com a infanta D. Isabel, filha de D. João I. Com o casamento de D. Fernando, irmão de D. Beatriz, e de D. Duarte, irmão de D. Isabel, o gineceu passou a ficar a cargo das cunhadas de ambas. Não se sabe de que forma se deu esta passagem. Terão algumas mulheres permanecido junto a D. Beatriz e a D. Isabel, para as servir? É de supor que, enquanto filhas e irmãs de reis, ambas tivessem mantido um grupo de servidoras junto a si. No caso de D. Isabel, sabe-se que Beatriz Gonçalves de Moura foi sua aia depois de o ter sido de sua mãe. A esta dúvida não se pode, por falta de informação nas fontes e bibliografia consultadas, responder com certezas.

Outra questão prendeu-se com a constituição de séquitos. A infanta D. Beatriz, filha de D. Fernando e D. Leonor Teles, teve um séquito próprio, que funcionaria como uma extensão do de sua mãe, que terá sido a responsável pela formação do grupo de servidoras de sua filha e

\footnotetext{
${ }^{140}$ PINA, Rui de - Crónica de D. Afonso V... p. 131.

${ }^{141}$ Idem, p. 48.

${ }^{142}$ Idem.

${ }^{143}$ Idem, p. 130.
} 
Silva, Mariana Faria da - As mulheres que acompanharam as rainhas de Portugal. Os séquitos femininos de Leonor Teles, Filipa de Lencastre e Leonor de Aragão (1371-1445). In Omni Tempore-Atas dos Encontros da Primavera 2020. Porto: FLUP, 2021. pp. 143-176.

da escolha das mesmas. Sabe-se que algumas das senhoras que serviram Leonor Teles passaram a servir a infanta, como foi o caso de Beatriz de Castro que, de acordo com Fernão Lopes, terá sido criada e donzela da rainha, que a encarregou de servir e acompanhar a sua filha, e também de Teresa de Meira, donzela da soberana e que terá sido aia de D. Beatriz. De que forma teria D. Leonor selecionado as mulheres que a iriam servir? Decerto terá escolhido aquelas em quem mais confiava.

Podemos supor que algumas das jovens criadas pela rainha, ao atingir a idade própria para contrair matrimónio, podiam passar a frequentar a Casa de outra senhora, rainha ou infanta ou de alguém com posses para sustentar um séquito, como foi o caso de Maria Teles.

Sobre a constituição dos séquitos, surgiu uma nova dúvida: quem escolheria as mulheres que iriam servir a rainha de Portugal? Seria o rei o responsável por essa escolha, ou encarregaria pessoas da sua confiança para o fazer? E de que forma seriam escolhidas as damas, quais seriam os critérios a seguir? Estas mulheres vinham da aristocracia, de famílias próximas à Coroa e que teriam ajudado o rei em algum momento. Podiam ser também parentes do rei ou da rainha. Com efeito, algumas das donzelas a quem Leonor Teles arranjou casamento eram suas familiares, como foi o caso de sua irmã ilegítima, Joana Teles, e de Inês Dias Botelho, sua parente (tentouse saber qual o grau de parentesco que a unia à rainha, mas sem sucesso). Junto de Leonor Teles estavam também duas irmãs, filhas de Álvaro Pires de Castro, primas dos filhos de Inês de Castro, irmãos de D. Fernando, o que mostra a influência desta família na corte régia.

Do séquito de D. Filipa de Lencastre fizeram parte senhoras que pertenciam a famílias que ajudaram D. João I durante a crise de 1383-1385. Beatriz Gonçalves de Moura e suas filhas Teresa, Leonor e Mécia Vasques Coutinho são exemplo disso, e a sua colocação na Casa da nova rainha poderia ter funcionado como um agradecimento pelo apoio prestado. O mesmo terá acontecido com a família de Nuno Álvares Pereira, pois junto de D. Filipa estiveram também Leonor e Beatriz Pereira e Berengária Nunes Pereira, suas familiares.

Verificou-se também que estas senhoras se encontravam ligadas entre si através de laços de parentesco, como se pode comprovar pelas árvores genealógicas construídas com base nas leituras efectuadas. É também de destacar que a influência de Leonor Teles estendeu-se pelo menos até ao reinado de $\mathrm{D}$. Afonso $\mathrm{V}$, visto que a sua esposa, D. Isabel, teve como aia Beatriz de Meneses, filha de Martinho de Meneses (filho de D. Gonçalo Teles de Meneses, irmão de Leonor Teles) e de Teresa Vasques Coutinho (membro da Casa de D. Filipa de Lencastre e uma das filhas de Beatriz Gonçalves de Moura).

Assim, a presença destas senhoras junto da rainha demonstrava a protecção dada pela Coroa a várias famílias do reino. Além disso, em muitos casos, a influência destas famílias 
prolongava-se por várias gerações e reinados, pois verificou-se que em muitos casos, filhas e netas de antigas damas de companhia, ingressavam também na corte junto de suas mães ou no gineceu de uma nova rainha. Tal verifica-se com Beatriz Gonçalves de Moura, cujas filhas e depois as netas, se encontravam na corte junto de Filipa de Lencastre.

Relativamente ao estado civil, podiam ser casadas ou viúvas (donas) ou solteiras (donzelas), existindo ainda as ricas-donas e as religiosas, pelo que as suas idades variavam muito. Desempenhavam diferentes cargos, verificando-se que as aias, camareiras e covilheiras seriam mulheres mais velhas e da confiança da soberana, pois tratavam da sua intimidade.

Estas mulheres, que rodearam as rainhas de Portugal, terão desempenhado um importante papel nas suas vidas e em muitas delas, as soberanas puderam ter encontrado verdadeiras amigas e conselheiras, que terão estado ao seu lado em momentos decisivos das suas vidas. A aia Beatriz Gonçalves de Moura, por exemplo, terá apoiado D. Filipa de Lencastre nos seus primeiros anos como rainha numa terra da qual desconhecia a língua e os costumes. Com efeito, ela e uma das suas filhas, estavam junto da soberana quando esta tomou conhecimento da partida do marido para Ceuta, em 1415 e antes de falecer, D. Filipa revelou preocupação com o futuro da sua aia e da sua filha. Também as mulheres que se mantiveram junto de Leonor Teles e Leonor de Aragão nos seus tempos de exílio, foram de grande importância para as soberanas.

Foram mulheres que, apesar dos seus próprios problemas e dilemas, se mantiveram junto das rainhas, observando, quase na sombra e ao lado das soberanas, muitos dos episódios que marcaram a História de Portugal.

\section{Fontes}

Chancelaria de D. João I (1385-1433). Vol. I, Tomo III. Ed. de João Alves Dias, Lisboa: Lisboa: Centro de Estudos Históricos da U.N.L., 2004.

LOPES, Fernão - Crónica de D. Fernando. Lisboa: Escriptorio, 1895-1896. (Biblioteca de clássicos portugueses).

LOPES, Fernão - Crónica de D. João I, segundo o códice n ${ }^{\mathrm{o}} 352$ do Arquivo Nacional da Torre do Tombo, introdução de Humberto Baquero Moreno e prefácio de António Sérgio. Porto: Livraria Civilização, 1983.

PINA, Rui de - Crónica de D. Afonso V. Lisboa: Escriptorio, 1904. (Biblioteca de Clássicos Portugueses). 
Silva, Mariana Faria da - As mulheres que acompanharam as rainhas de Portugal. Os séquitos femininos de Leonor Teles, Filipa de Lencastre e Leonor de Aragão (1371-1445). In Omni Tempore-Atas dos Encontros da Primavera 2020. Porto: FLUP, 2021. pp. 143-176.

ZURARA, Gomes Eanes - Crónica da Tomada de Ceuta. Publicada por ordem da Academia das Ciências de Lisboa segundo os manuscritos no 368 e 355 do Arquivo Nacional por Francisco Maria Esteves Pereira. Lisboa: Academia das Ciências, 1915.

\section{Bibliografia}

BALEIRAS, Isabel de Pina - Uma rainha inesperada. Leonor Teles. Lisboa: Círculo de Leitores, 2012. ISBN 978-972-42-4706-9.

BENEVIDES, Francisco da Fonseca - Rainhas de Portugal (1879). Barcarena: Marcador, 2011. ISBN 978-989-8470-18-8.

FREIRE, Anselmo Braamcamp - Brasões da Sala de Sintra. Coimbra: Imprensa da Universidade de Coimbra, 1921.

GOMES, Rita Costa - A Corte dos Reis de Portugal no Final da Idade Média. Oeiras: Difel, 1995. ISBN 97229-0319-5.

OLIVEIRA, Ana Rodrigues - Rainhas Medievais de Portugal. Lisboa: A Esfera dos Livros, 2010. ISBN 978-989-626-261-7.

RODRIGUES, Ana Maria S. A. - As tristes rainhas. Leonor de Aragão, Isabel de Coimbra. Lisboa: Círculo de Leitores, 2012. ISBN 978-972-42-4708-3.

RODRIGUES, Ana Maria S. A., SILVA, Manuela Santos, FARIA, Ana Leal (dir.) Casamentos da Família Real Portuguesa. Diplomacia e cerimonial. Lisboa: Círculo de Leitores, 2017. ISBN 978-972-42-5120-2.

SERRANO, César Oliveira - Beatriz de Portugal. La pugna dinástica Avís-Trastámara. Galiza: Instituto de Estudios Gallegos, 2005. ISBN 84-00-08343-1.

SILVA, Manuela Santos - A Rainha Inglesa de Portugal. Filipa de Lencastre. Lisboa: Círculo de Leitores, 2012. ISBN 978-972-42-4707-6.

SOUSA, António Caetano - História Genealógica da Casa Real Portuguesa. 13 volumes, Lisboa Ocidental: Na Officina de Joseph Antonio da Sylva, 1735-1749. Disponível em WWW:<URL:https://purl.pt/776>.

SYLVA, Joseph Soares - Memorias para a Historia de Portugal que comprehendem o governo Del Rey D. João I do anno de mil e trezentos e oitenta e três, até o anno de mil e quatrocentos e trinta e três. [Em Linha] Lisboa Ocidental: Na Officina de Joseph Antonio da Sylva, 1730-1734. Disponível em WWW:<URL: https://archive.org/details/memoriasparahist03soar>. 


\section{Anexos}

\section{Árvore Genealógica 1 - Os Teles e os Castro.}

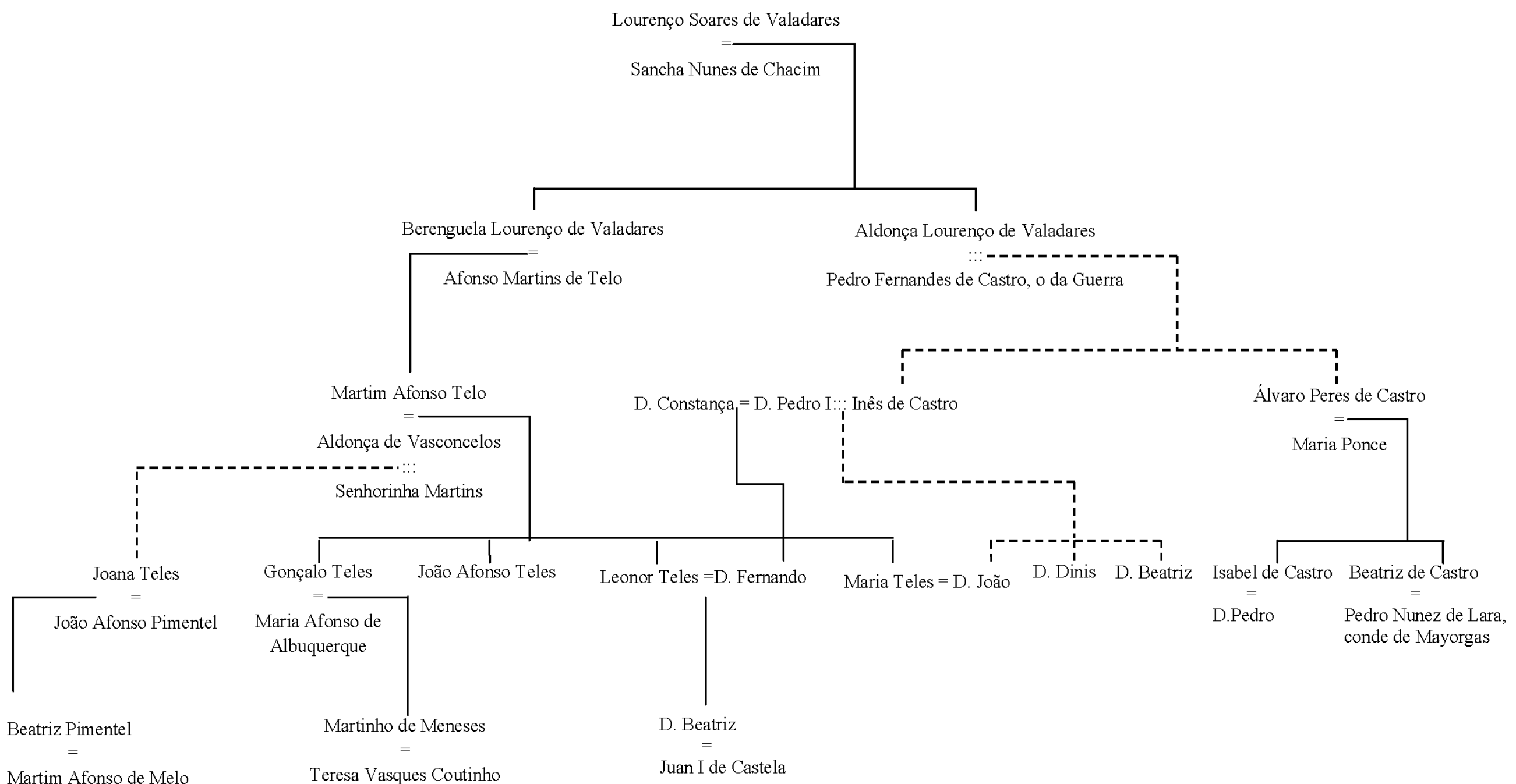




\section{Árvore Genealógica 2 - Ligações de parentesco entre algumas damas dos séquitos de Leonor Teles e Filipa de Lencastre.}

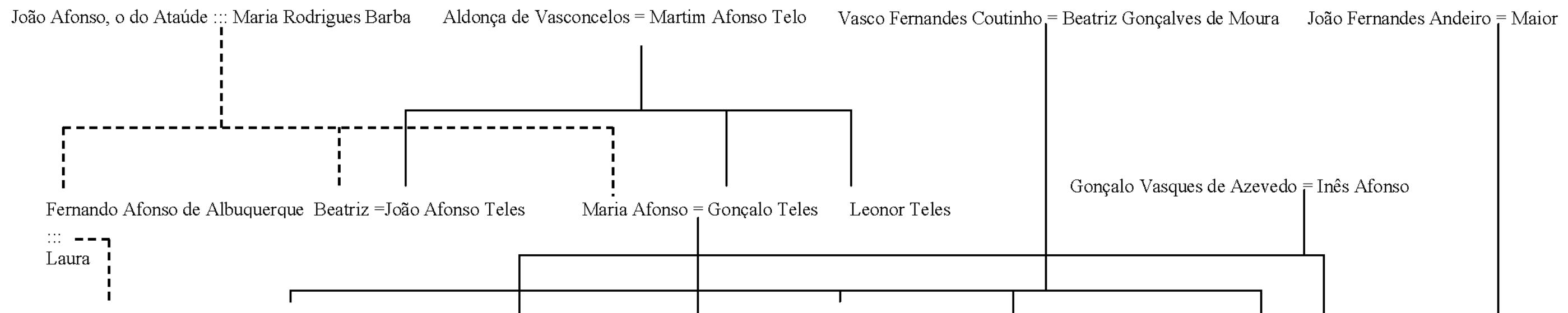

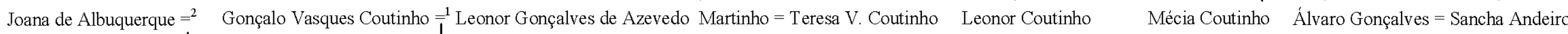

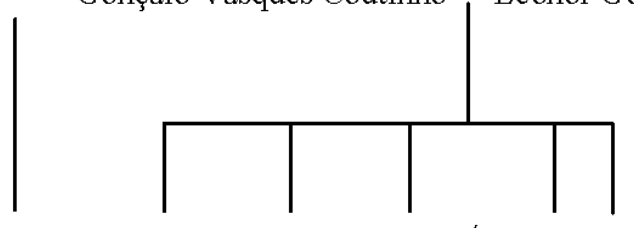

Isabel Coutinho Filipa Vasco Fernão Álvaro Luís

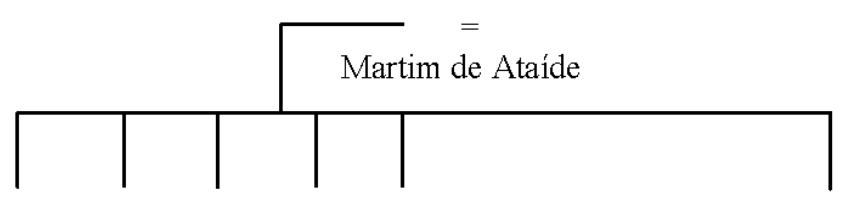

Álvaro Vasco Isabel Helena Filipa de Ataíde Catarina de Ataíde 


\section{Árvore Genealógica 3 - Os Pereira.}

Urraca Vasques Pimentel $=^{1}$ Gonçalo Pereira :.: ?

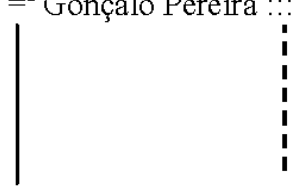

? :.: Gonçalo Pereira

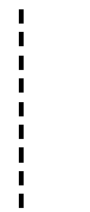

Iria Gonçalves do Carvalhal :..: Álvaro Gonçalves Pereira

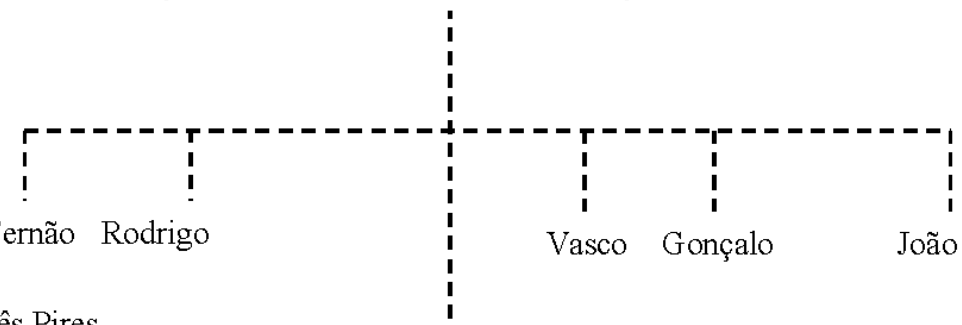

D. João I $\cdots$ Inês Pires

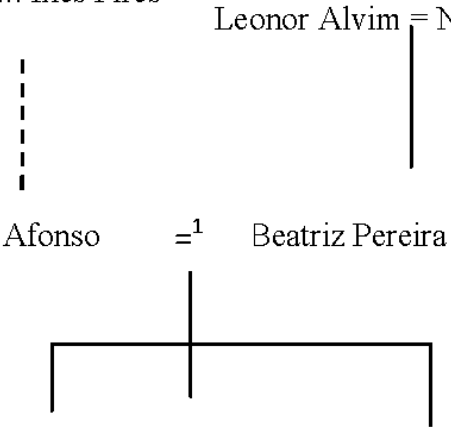

Afonso
Fernando
Rui Gonçalves Pereira $=$ ?

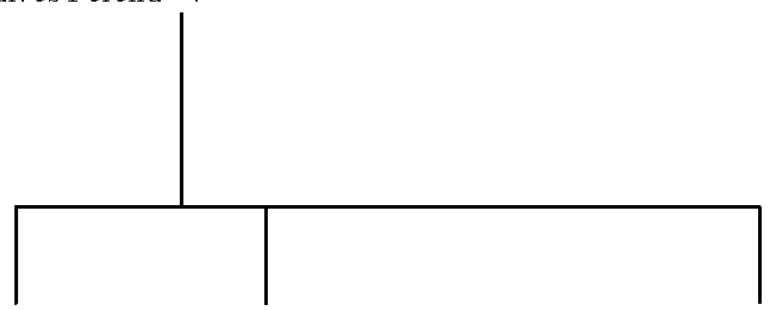

Gonçalo Pereira

Álvaro Pereira $=$ ?

Rui Pereira =?

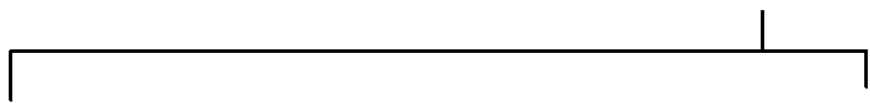

Berengária Nunes Pereira

Afonso Vasques Correia

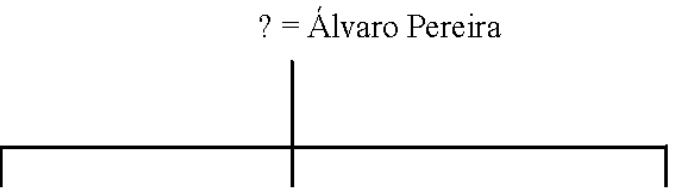

João Álvares Pereira

Beatriz Pereira Leonor Pereira

Leonor

Martim Vasques de Resende

Gomes Freir

Gonçalves

Melo

Fernão Pereira 


\section{Árvore Genealógica 4 - Ligação de Maria de Vasconcelos à família real.}

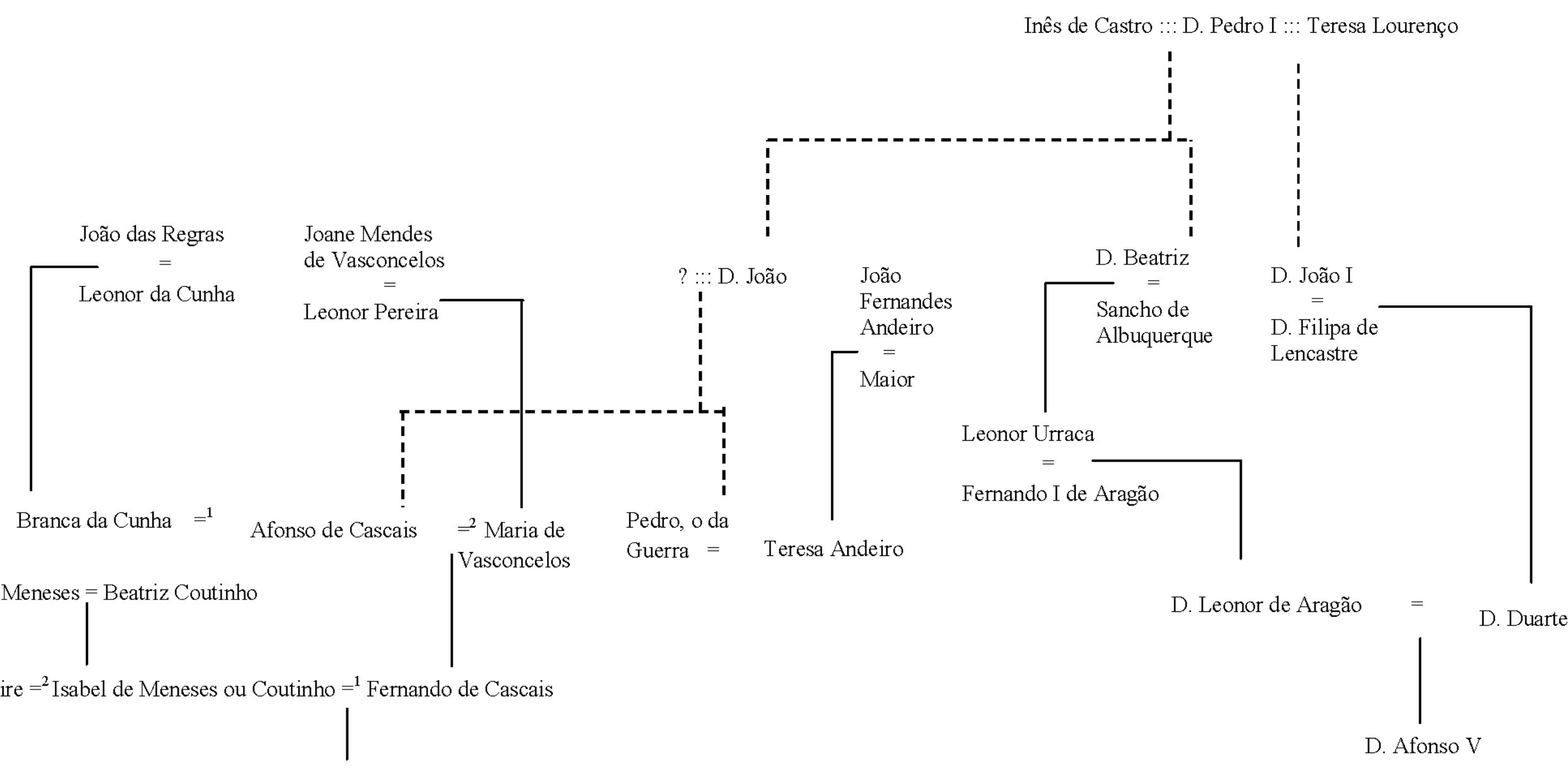

filho 